ANUARIO DE Estudios Medievales 51/1, enero-junio de 2021, pp. 303-337

ISSN 0066-5061

https://doi.org/10.3989/aem.2021.51.1.10

\title{
DE COMPOSTELA A TOLEDO: UNA PANORÁMICA EN TORNO AL PATRONAZGO ARTÍSTICO DEL ARZOBISPO GÓMEZ MANRIQUE $(† 1375)^{*}$
}

\author{
FROM COMPOSTELA TO TOLEDO: A PANORAMIC VIEW OF \\ THE ARTISTIC PATRONAGE OF ARCHBISHOP GÓMEZ MANRIQUE (†1375)
}

\author{
José AlBerto MORÁIS MORÁN \\ Instituto de Estudios Medievales, Universidad de León \\ https://orcid.org/0000-0002-0069-5864
}

\begin{abstract}
Resumen: Esta investigación analiza el patronazgo artístico del arzobispo don Gómez Manrique, reflexionando sobre su cursus honorum y las obras que financió en las catedrales de Santiago de Compostela y Toledo y los monasterios de Nuestra Señora de Sopetrán y San Bartolomé de Lupiana. Un estudio global de una vida marcada por la instrumentalización del poder de la corona y los ambientes de crisis en los que desarrolló su actividad político-religiosa permite explicar la naturaleza de los encargos arquitectónicos y artísticos que realizó. El análisis documental, el arqueológico y el de las empresas conservadas demuestra, en las obras gallegas, el apego a una tradición artística conservadora, de carácter defensivo y rudas formas que dejó paso, años más tarde, a los escenarios artísticos renovados y de gran empaque de la diócesis toledana.
\end{abstract}

Palabras clave: Arzobispo Gómez Manrique; Santiago de Compostela; Toledo; Sopetrán; Lupiana; patronazgo.

Abstract: This article analyses the artistic patronage of Archbishop Gómez Manrique, reflecting on his cursus honorum and the works he financed in the cathedrals of Santiago de Compostela and Toledo and the monasteries of Nuestra Señora de Sopetrán and San Bartolomé de Lupiana. A global analysis through the lens of a life marked by the instrumentalisation of the power of the crown and the atmosphere of crisis in which he undertook his political and religious activity allows us to explain the nature of the architectural and artistic works that he commissioned. Documentary and archaeological research, along with the analysis of preserved works, reveal an attachment to a conservative artistic tradition, of a defensive nature and severe forms, in the Galician works, which gave way to the more renewed and sumptuous artistic scenarios found in the diocese of Toledo in subsequent years.

Keywords: Archbishop Gómez Manrique; Santiago de Compostela; Toledo; Sopetrán; Lupiana; patronage.

\section{SUMARIO}

1. Los orígenes del prelado.- 2. Santiago de Compostela: la capilla funeraria en la torre y la ampliación del palacio episcopal.- 3. Toledo.- 4. Guadalajara y Nuestra Señora de Sopetrán.- 5. San Bartolomé de Lupiana.- 6. Bibliografía citada.

\footnotetext{
" Esta investigación se ha elaborado en el marco del proyecto "El patronazgo artístico en el reino de Castilla y León (1230-1500). Obispos y Catedrales II" (HAR2017-88045), financiado por el Ministerio de Ciencia, Innovación y Universidades y fondos FEDER. Agradezco la ayuda del Dr. Ramón Yzquierdo Peiró, Director del Museo de la Catedral, al facilitarme numerosos datos, fotografias y acompañarme durante el trabajo de campo que realicé en Santiago de Compostela para materializar este artículo.

Citation / Cómo citar este artículo: Moráis Morán, José Alberto (2021), De Compostela a Toledo: una panorámica en torno al patronazgo artístico del arzobispo Gómez Manrique (†1375), “Anuario de Estudios Medievales” 51/1, pp. 303-337. https://doi.org/10.3989/aem.2021.51.1.10

Copyright: (C) 2021 CSIC. Este es un artículo de acceso abierto distribuido bajo los términos de la licencia de uso y distribución Creative Commons Reconocimiento 4.0 Internacional (CC BY 4.0).
} 


\section{LOS ORÍGENES DEL PRELADO}

Uno de los autores que trató con mayor detenimiento la figura del arzobispo Gómez Manrique (1348-1375), D. Antonio López Ferreiro, ya lamentaba en 1903 las lagunas documentales que sobre este prelado existían en el archivo compostelano ${ }^{1}$. Años después, la Dra. Ana Arranz, otra de las contadas especialistas que abordó monográficamente su figura, insistía en que la documentación, escasa, no permitía trazar una biografía detallada del personaje ${ }^{2}$.

A pesar de ello, con seguridad podemos afirmar que Gómez Manrique, Gomerius, falleció en Toledo en el año 1375, poniendo fin a un cursus honorum que le había llevado, en diferentes cargos, por las sedes de León, donde, parece, fue subdiácono y deán; por Tuy, donde fue obispo entre 1348 y 1351, pasando a regir la diócesis de Santiago de Compostela, donde fue arzobispo entre 1351 y 1362. Finalmente ocuparía este cargo en la catedral primada de Toledo a partir de ese año y hasta su fallecimiento en $1375^{3}$.

Posiblemente oriundo de Toledo, perteneció a una de las familias más prestigiosas de Castilla: los Manrique de Lara, formando parte de una saga de prelados que en el siglo XIV ocuparían las sedes de Tuy, Compostela, Toledo, Sigüenza, Burgos, Jaén, Sevilla y Coria ${ }^{4}$.

En el siglo XVII el monje benedictino Gregorio de Argaiz escribió: el primer obispado que tuvo fue el de Palencia ${ }^{5}$, mientras que Fray Antonio de Heredia repitió este dato en 1675, asumido también por López Ferreiro ${ }^{6}$. Sin embargo la documentación manejada por Konrad Eubel no confirma este supuesto $^{7}$.

La fidelidad de don Gómez, primero a Pedro I y, más tarde, al apoyar la causa Trastámara, a Enrique II, le otorgó un puesto relevante en la política eclesiástica del siglo XIV ${ }^{8}$. En 1354 era Capellán Mayor del Rey, Notario Mayor del reino de León y Canciller Mayor de la Reina doña Blanca, mostrándonos un obispo siempre cercano a la realeza. De hecho, la Crónica de Pedro López de Ayala lo muestra así: Gómez Manrique Arzobispo de Toledo, que era muy grand perlado, e de grand linaje, e tenia consigo buena Compaña de Omes de armas $^{9}$ y precisamente, parece, más supo de

1 "Escasos son los documentos que se conservan de aquella época": López 1903, vol. VI, p. 141.

${ }^{2}$ Arranz 1988, p. 309.

${ }^{3}$ Nieto 1993, p. 445; Díaz 2006.

${ }^{4}$ Díaz 2005.

${ }^{5}$ Argaiz 1675, vol. I, pp. 136-139, cap. CXXXIV.

${ }^{6}$ Heredia 1676, p. 102; López 1903, vol. VI, p. 141.

${ }^{7}$ Eubel 1913, vol. I, pp. 487-501.

${ }^{8}$ Villarroel 2013, p. 319.

${ }^{9}$ López de Ayala, Crónicas, p. 546. 
política y guerra que de cultura, pues no tenemos constancia de que tuviese formación universitaria ${ }^{10}$.

Descartada su presencia en Palencia, poco sabemos sobre sus años en León e, igualmente, la información existente sobre su episcopado en Tuy es exigua. Eubel indica que fue subdiácono y deán en la sede legionense, pero la documentación conservada en la catedral y revisada no aporta pergamino alguno donde aparezca con claridad.

La nebulosa domina su presencia en Tuy. Ocupó la cátedra el 18 de agosto de 1348 con la confirmación del papa Clemente VI y, entre sus primeras acciones, dio protección al monasterio benedictino de San Salvador de Barrantes (Pontevedra), anexionándolo a la catedral de Santiago ${ }^{11}$. Se confirma tempranamente algo relevante: el amparo que don Gómez dio a la vieja orden y que no abandonaría a lo largo de su vida.

\section{SANTIAGO DE COMPOSTELA: LA CAPILlA FUNERARIA EN LA TORRE Y LA AMPLIACIÓN DEL PALACIO EPISCOPAL}

Los parcos datos que poseemos del inicio de su carrera eclesiástica son más ricos a partir de la llegada a Santiago de Compostela. Durante su primer año de mandato, Gómez Manrique ya aparece involucrado en la obra catedralicia. En 1351 el rey Pedro I emitió en Valladolid un Ordenamiento de Menestrales que provocó ciertas dudas en el cabildo santiagués sobre los pechos con que debían contribuir al Concejo los canteros y demás oficiales de las obras de la catedral. Dicho Concejo les quería hacer pagar toda clase de pechos y ello provocó una reclamación de los oficiales ${ }^{12}$. En este conflicto fue Manrique quien elevó la queja al rey para que aclarase cuáles de ellos debían pagar, recibiendo el prelado finalmente el apoyo del monarca frente al Concejo ${ }^{13}$. Si a ello sumamos que desde 1354 don Gómez aparece como canciller de la reina doña Blanca y notario mayor del reino de León, confirmamos el respaldo de la monarquía en sus actuaciones políticas y, posiblemente, en las empresas artísticas que comandó en la sede del Apóstol.

\footnotetext{
${ }^{10}$ Arranz 2006, p. 175.

${ }^{11}$ Flórez 1767, pp. 261-262.

${ }^{12}$ López 1903, vol. VI, p. 151.

${ }_{13}^{13}$ Ibidem, p. 152, Tumbo B, f. 278, citado en González 2004: "Sepades que el arçobispo et Cabildo de la elgesia de la dicha cibdat se me enviaron querellar et dizen que seyendo los pedreros que labran en la lauor et obra de dicha iglesia et los otros oficiales de dicha iglesia et sus mujeres quitos de todos los pechos et pedidos que se ascasciesen en la dicha cibdat en qualquier manera por cartas et pruilleios".
} 
La querella abierta contra los oficiales y pedreros no impidió que en 1351 el arzobispo emprendiese obras de envergadura. La primera de ellas, prácticamente arrasada, fue una torre de enormes de dimensiones, de potente sillería granítica, posiblemente con tres pisos y que se integró en el área del claustro medieval de la catedral compostelana (fig. 1) ${ }^{14}$. El baluarte se adosaba al muro sur de la basílica románica, correspondiendo, al exterior, aproximadamente con los tramos quinto y séptimo de las naves. La potencia de la construcción es muy remarcable incluso analizando sus maltrechos vestigios, visibles bajo el suelo del claustro (fig. 2), en la zona arqueológica de la Buchería, donde perduran los cimientos y zapatas que sirven de base a un muro $(15,22$ metros) que presenta, en su costado oeste, forma escalonada, menos pronunciada en el lado este, tal y como dibujó Eduardo Carrero. Un vano de 3,20 metros se abre en dicho muro. Como luego se discutirá, la torre albergó varias funciones en los distintos pisos.

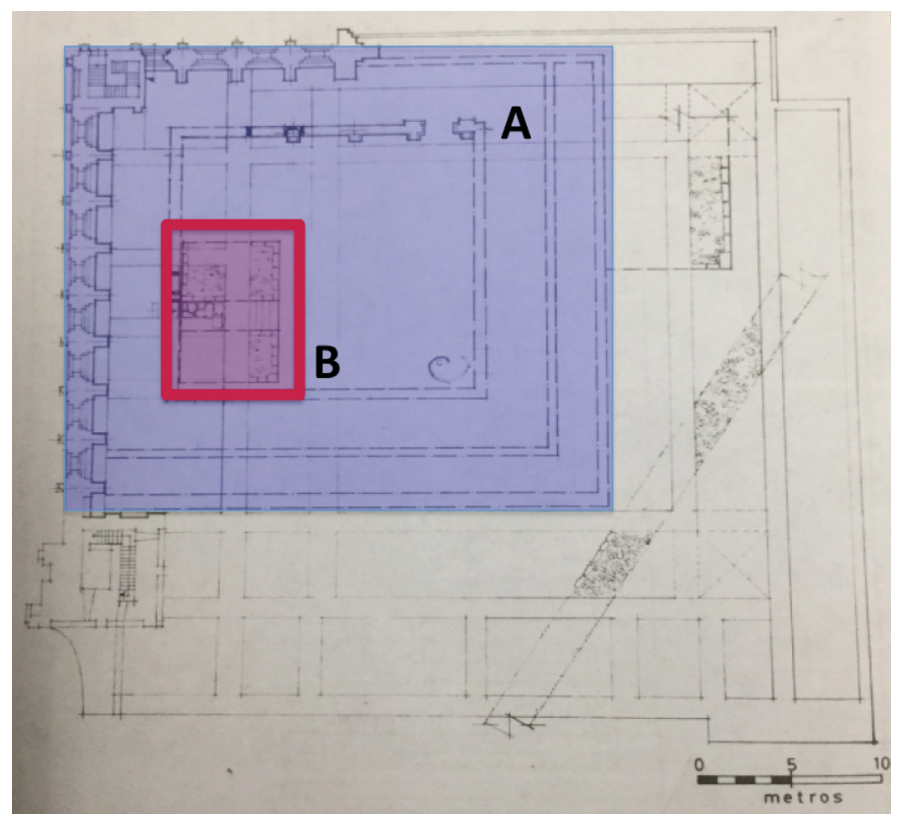

Fig. 1. Claustro tardorrománico (A) y torre de don Gómez Manrique (B), catedral de Santiago de Compostela. Plano de R. Yzquierdo Perrín (1989).

${ }^{14}$ Las tres aportaciones fundamentales para conocer la torre son: López 1903, vol. VI; Yzquierdo 1989; Carrero 1997-1998. El trabajo de este último investigador es muy valioso para esta cuestión y aún hoy posee plena vigencia. 


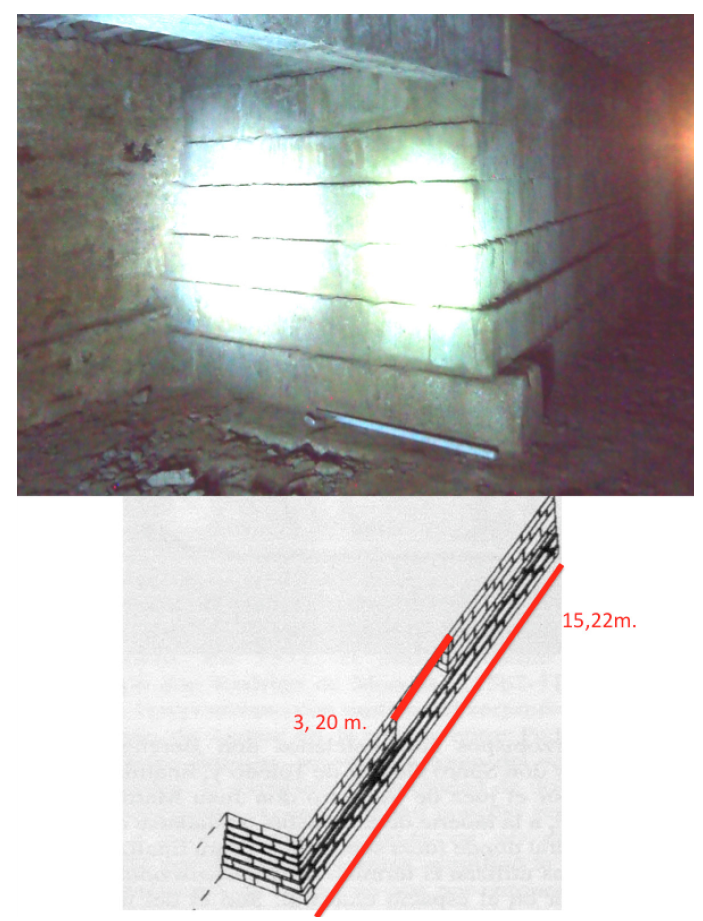

Fig. 2. Restos de la torre de Gómez Manrique, catedral de Santiago de Compostela. Foto del autor y dibujo de E. Carrero Santamaría (1997-1998).

Estos restos, desconocidos hasta las excavaciones realizadas por Chamoso Lamas ${ }^{15}$ y continuadas por Suárez Otero en la Buchería y la Capilla de las Reliquias, han tenido escasa repercusión en la bibliografía posterior $^{16}$.

A pesar de la desaparición de la obra comandada por don Gómez consideramos que, cotejando estos restos con las fuentes documentales y las noticias conservadas sobre su periplo vital y la realidad artística de la época en que vivió podemos aportar datos sobre su labor comitente.

El piso bajo de la torre fue proyectado para enterramiento y de ello da cuenta la documentación que informa sobre el acta de fundación de una capilla funeraria el día 4 de octubre de $1361^{17}$.

\footnotetext{
${ }^{15}$ Chamoso 1971, pp. 35-48.

${ }^{16}$ Conant 1983. La obra original inglesa, del año 1926, fue editada en español sin incluir este hallazgo.

${ }^{17}$ López 1903, vol. VI, p. 156. No obstante, en ese momento el erudito canónigo pensaba que la torre estaba en "uno de los ángulos del claustro, que suponemos sería el SO".
} 
El dato confirma la voluntad de terminar su cursus honorum en Compostela. Ese año mandó que cuatro capellanes sirviesen la capilla. Éstos debían celebrar diariamente misa cantada, la primera de Requiem, la segunda por Nuestra Señora, la tercera dedicada a Santiago y la cuarta en honor de Santa María Magdalena. La capilla, dictó don Gómez, albergaría la misa cantada del oficio divino y, tras ella, debía rezarse un responso por el fundador. A la muerte del arzobispo las misas pasarían a ser de Requiem, especificando el documento que el cabildo debería celebrar fiesta mitrada el día de la Magdalena y, al día siguiente, un aniversario ${ }^{18}$. Esta devoción personal empieza a revelar una tendencia conservadora en sus comportamientos litúrgicos y, como veremos, artísticos, de respeto a la tradición compostelana, a su catedral románica y a las fórmulas estilísticas del pasado. Como es sabido, la presencia de la Magdalena se remontaba a los días del arzobispo Gelmírez y perduraría hasta la Baja Edad Media cuando el arzobispo Isorna $(† 1448)$ mandó pintar en su tumba la imagen de Nuestra Señora con su Santísimo hijo y la de María Magdalena ${ }^{19}$.

El apego a la tradición imperó en las formas artísticas elegidas por don Gómez Manrique a mediados del siglo XIV en Galicia. La desaparecida torre, una de sus empresas más notables, no se comprende sin adentrarnos en la complejidad del claustro medieval de la catedral santiaguina.

Hasta 1256 la canónica compostelana contó con un espacio para las reuniones del cabildo ${ }^{20}$. Ese año fue relevante en el conjunto catedralicio, pues el arzobispo Juan Arias (1238-1266) puso todos sus esfuerzos en la construcción de un nuevo templo gótico sobre terrenos propiedad del monasterio de Antealtares, desapareciendo así la canónica al iniciarse la cabecera y trazarse los cimientos y las primeras hiladas del muro. Como es sabido, esa catedral nunca pasó de ahí.

A mediados del siglo XIII el mecenazgo artístico de Juan Arias era vanguardista, rechazando el románico frente a los punteros modelos leoneses de Nuestra Señora de Regla ${ }^{21}$. No obstante, cuando por lo general tendemos a imaginar cierta homogeneidad en los gustos de los promotores episcopales, el caso de Arias revela lo contrario. Por las mismas fechas patrocinaba otra gran empresa: un claustro que, ya en torno a 1250 estaba finalizado ${ }^{22}$. Los vestigios de la desaparecida obra revelan la elección de formas románicas.

\footnotetext{
${ }^{18}$ Ibidem, vol. VI, p. 157.

${ }^{19}$ López 1904, vol. VII, p. 184.

${ }^{20}$ Carrero 1997-1998; 2005, pp. 298-311.

${ }^{21}$ Puente 1985, p. 249.

${ }^{22}$ Yzquierdo 1989.
} 
Para comprender las empresas y decisiones tomadas un siglo después por don Gómez es necesario valorar el carácter funerario que adquirió ese claustro, donde Juan Arias quiso recibir sepultura, según expresó en su testamento del 2 de abril de 1266. Para ello financió una capilla en el área oriental, panda este, anexa a la puerta de las Platerías. También destruida, la arqueología y las fuentes revelan que esa torre contó con una planta baja dedicada a eventual sala capitular $^{23}$. Sin embargo, por encima de estos usos, fue diseñada para albergar el enterramiento del arzobispo en ese espacio, mientras que en otro nivel superior se ubicó el tesoro. Esta desaparecida torre/capilla funeraria, sala capitular/tesoro sirvió hasta el siglo XV de enterramiento a otras personalidades, mencionándose en la documentación como la capilla de los arzobispos ${ }^{24}$.

Con todo, estos usos del baluarte se discutieron ${ }^{25}$. López Ferreiro e Yzquierdo Perrín negaron la ubicación en esta torre del capítulo, indicando que se situó en el tesoro de la torre nova mencionada en las fuentes ${ }^{26}$, del mismo modo, por ejemplo, que ocurrió en otras catedrales hispanas ${ }^{27}$.

Dejando a un lado estas disquisiciones lo que no parece debatible es que durante largo tiempo la torre del prelado Juan Arias debió considerarse un referente simbólico del claustro. La acreditada personalidad de este comitente y la novedosa solución que adoptó para prestigiar su última morada fueron un antecedente clave para el proyecto manriqueño. La torre nova se proyectó en la panda del mandatum, al tiempo que la torre de Arias aún estaba en uso. El arrasamiento de la construcción pide cautela en las hipótesis pero con seguridad conocemos la morfología de su perímetro y la articulación del espacio interior de la planta baja.

Algunos vestigios del alzado de la torre se conservan embutidos en las construcciones modernas, especialmente en la Capilla de las Reliquias y el pasaje a la Capilla de San Fernando, donde existe una ventana cegada y parte del remate del baluarte (fig. 3), con arcos ciegos apeados sobre ménsulas, una de ellas con la cabeza de un ser fantástico de tradición románica ${ }^{28}$. Estos elementos confirman la imagen de un proyecto muy conservador.

\footnotetext{
${ }^{23}$ Sobre los cambios, constantes, de su emplazamiento en la topografía catedralicia: Carrero 1997-1998, p. 39.

${ }^{24}$ Entre ellos, véase el caso del arzobispo Isorna (1445-1449), enterrado en la torre del prelado Juan Arias de la panda oriental del claustro, según Carrero 1997-1998, p. 41.

${ }^{25}$ Ibidem, p. 36.

${ }^{26}$ López 1903, vol. VI, p. 156; Yzquierdo 1989, p. 16.

${ }^{27}$ En Lugo la sala capitular se ubicó temporalmente en el tesoro sobre la capilla de San Bartolomé: Carrero 1997-1998, nota 9.

${ }^{28}$ Ibidem, p. 42. En este punto agradezco la ayuda del Dr. Javier Castiñeiras González (Centro Ramón Piñeiro para a Investigación en Humanidades, Xunta de Galicia), buen conocedor de la arquitectura medieval gallega.
} 


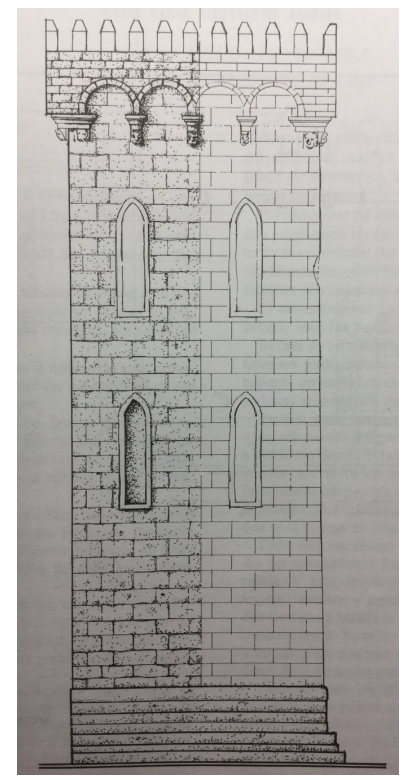

Fig. 3. Dibujo de la torre de Gómez Manrique, catedral de Santiago de Compostela. Diseño de R. Yzquierdo Perrín y A. Barral (1989).

La fábrica, rotunda y potente, pudo elevarse hasta los 20 metros. En el nivel bajo, de planta cuadrangular y del que hemos perdido cualquier rastro del abovedamiento, se ubicó la capilla funeraria de don Gómez ${ }^{29}$, a la que se accedía únicamente desde el claustro, mientras que la parte trasera se adosaba a la cimentación del edificio románico, salvando el gran desnivel que existía entre la cota de las naves de la basílica y la cimentación de la torre. Ello explica que al primer piso del torreón se accediese directamente desde la nave sur de la catedral.

El financiamiento de un espacio mortuorio de esta envergadura se explica a partir de diversos factores, siendo el más relevante el apoyo absoluto del rey Pedro I. En un documento de 1354 el monarca eximió a los pedreros que labran en la lauor et obra de la dicha iglesia et los otros oficiales de la dicha eglesia ${ }^{30}$, lo que confirma la actividad edilicia al servicio del arzobispo, quien ideaba, o quizás ya materializaba, los cimientos de la torre.

Sin embargo, la suerte del prelado cambió en 1362, cuando sorpresivamente fue promovido a Toledo y su intención de enterrarse en la capilla

\footnotetext{
${ }^{29}$ Carrero indica, al contrario, que "en los pisos de la torre" se dispuso la capilla funeraria del arzobispo: ibidem, p. 42.

${ }^{30}$ López 1903, vol. VI, pp. 152-153, Tumbo B, f. 278: González 2004.
} 
cambió, quedando la obra inconclusa. No podemos concretar el modo en que continuaron las obras ni el grado de implicación de sus sucesores. No obstante, considero que existen razones para pensar que durante el gobierno de Rodrigo de Moscoso (1368-1382) el proyecto no fue retomado, tal y como pasamos a explicar.

Tras la llegada a la cátedra compostelana de su sobrino, Juan García Manrique (1382-1399), las fuentes confirman la finalización de la obra iniciada por su tío. Sabemos que en 1392 las reuniones capitulares las presidía don Juan en el tesoro de esta torre nova que ya por entonces, ahora sí, estaba acabada y en uso ${ }^{31}$. No resulta posible, por la destrucción, identificar las fases edilicias de uno y otro prelado. En todo caso concluimos que, por la potencia de los cimientos y muros, la altura que tuvo y su posición en el interior del inexpugnable claustro, el modelo turriforme: 1) buscaba una seguridad y fortaleza mayor que la alcanzada en la torre de Juan Arias, más vulnerable y 2) el proyecto integral, con todos sus niveles y funciones, debe atribuirse a don Gómez quien, desde el inicio, supo lo que quería construir y cómo, limitándose su sobrino a terminar la empresa de su tío. Ello explica el uso inicial de tan potentes cimientos.

La obra manriqueña se diseñó no sólo como espacio memorial. Aunaba los usos funerarios y atendía al contexto bélico de la ciudad, en plena crisis, marcado por la guerra civil y con enfrentamientos entre el Concejo y el cabildo. Ya desde la mitra toledana don Gómez conoció los sucesos acaecidos en Compostela en 1371, cuando se produjeron desacuerdos entre el arzobispo Rodrigo de Moscoso y el Concejo, agudizados con la irrupción de algunos de sus miembros en el claustro para encerrar al cabildo durante nueve días en la torre de Juan Arias. Hechos como estos justifican el abandono de la expugnable torre vieja como espacio del tesoro, pero sobre todo explican cómo, entre 1371 y 1392, don Juan acometió la finalización de la obra de su tío.

A pesar del dilatado proceso de construcción de la torre, don Gómez dispuso todo para recibir sepultura aquí. La escritura de fundación especificaba que mientras tanto no se terminase la obra de la capilla, habrían de decirse (las misas) en el leedoiro del coro ${ }^{32}$, noticia valiosa que informa sobre el mobiliario litúrgico vinculado al maestro Mateo y que en el siglo XIV se usaba también como área cementerial ${ }^{33}$.

\footnotetext{
${ }^{31}$ Ibidem, p. 254.

${ }^{32}$ Ibidem, p. 157: ubica el "legitorio chori" en el gran púlpito o tribuna que ocupaba el fondo del coro.

${ }^{33}$ Conant 1983 , p. 53, señala que en el "legitorio" de la catedral compostelana se celebraban los capítulos, antes de que estuviera lista la torre nueva. Este investigador la dató entre 1352 y 1356, aunque la ubicó "en el recanto sudoeste del claustro".
} 
Por otra parte, el promotor, don Gómez, sabía que la magna obra se dilataría durante esos aciagos años y por ello donó al cabildo, en 1361, los casales de Loenso, Surriba, Juno, Adranes y Seira, para pagar, con los 2400 maravedíes anuales, a los cuatro capellanes que se dedicarían a este cargo ${ }^{34}$.

Por último se constata la tendencia continuista diseñada por Manrique, prosiguiendo con la fortificación de la catedral iniciada por Juan Arias y que había tenido sus momentos más relevantes durante el arzobispado de Rodrigo Padrón (1304-1316) y su sucesor Berenguer de Landoira (1318$1330)^{35}$. El encastillamiento de la sede buscó la defensa de la iglesia y del palacio, en el marco de fuertes enfrentamientos entre el cabildo y el poder municipal que provocaron grandes cambios en el templo románico: se elevaron las cornisas, se proyectaron parapetos almenados, paseos de ronda y se sustituyó la cubierta de teja por otra de piedra, resistente a los incendios y que permitía el paso de hombres y maquinaria de guerra ${ }^{36}$. La idea de una catedral gótica, frágil relicario vidriado se desvaneció para siempre, mientras que la robusta arquitectura románica se adaptaba mejor a los tiempos inciertos.

En este marco artístico se forjaron tanto el patronazgo como las predilecciones estéticas de don Gómez, conservadoras, apegadas a las labores de sus antecesores, técnica y morfológicamente, incluso para su morada perpetua.

La ubicación de su baluarte/capilla funeraria siguió la vieja usanza compostelana, en un claustro marcado por el sello funerario arzobispal desde los días de Arias y rechazando don Gómez el enterramiento, supuestamente más prestigioso, del leedoiro del coro mateano ${ }^{37}$. Nada hacía presagiar aún el rumbo que tomaría su cursus honorum, ni tampoco nada permitía, desde Galicia, imaginar el cambio de gusto y sus preferencias en cuanto al lugar de sepultura, que en la primada de Toledo variaron radicalmente.

Para el modelo arquitectónico de su torre eligió soluciones que remiten a la arquitectura militar civil, antes que a la religiosa. Las formas defensivas y robustas de la base que conservamos se ven acusadas por la pérdida de las labores escultóricas y pictóricas que tuvo el baluarte y cuyos restos conocemos fragmentariamente. Algunos se hallaron durante las excavaciones de las décadas pasadas y otros aparecieron recientemente, conservándose in situ y en el Museo de la Catedral ${ }^{38}$.

\footnotetext{
${ }^{34}$ López 1903, vol. VI, p. 157.

${ }^{35}$ Díaz 1983; Vázquez 1998, p. 112; Conant 1983, p. 96. Este último autor remonta el proyecto de fortificación a los tiempos de Cresconio (1037-1066).

${ }^{36}$ Vázquez 2015, p. 155.

${ }^{37}$ Otero, Yzquierdo 1990.

${ }^{38}$ Carrero 1997-1998, pp. 42-43 indica que los restos de pintura mural "de fines del siglo XV" encontrados por Chamoso en la excavación pasaron al Museo de las Peregrinaciones. Sin embargo, según me informaron el 28 de octubre de 2018 la directora del Museo, Dña. Espe-
} 
El interior del piso bajo, la capilla funeraria, presenta restos de policromía aplicados sobre un enlucido de calidad que ha permitido su conservación (fig. 4). Se decoró con un sistema de cuadrícula blanca a la que se dio profundidad mediante dos trazos rojos y un fondo azulado, motivo universal de reminiscencias romanas ${ }^{39}$ que podemos vincular al mecenazgo de don Gómez, pues su espacio sepulcral debía estar terminado, y pintado, cuando fue trasladado a Toledo.

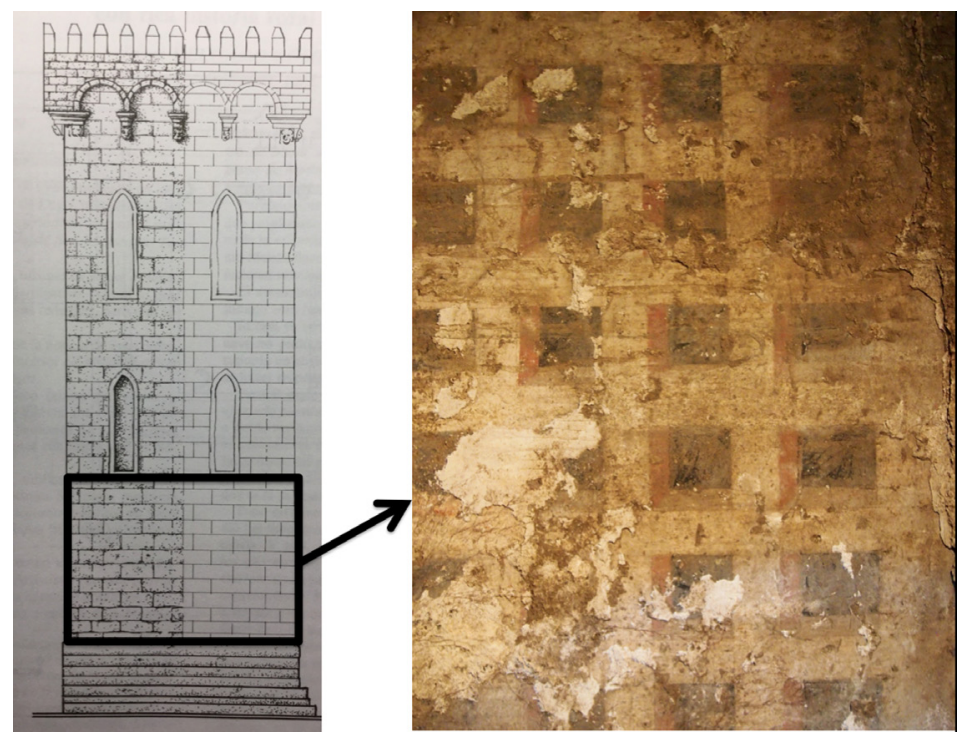

Fig. 4. Restos pictóricos de la torre, catedral de Santiago. Foto del autor.

El vestigio de mayor calidad es el del elegante ángel músico que toca un órgano de mano que apoya sobre sus rodillas (fig. 5) ${ }^{40}$, con túnica rozagante de gran empaque en tonos blancos y perfilada con líneas negras y degradados grises. Aquí trabajó un pintor hábil, que captó la sutileza de las alas, de las facciones y cabellos, todo en contraste con el rojo vívido del fondo. Este fragmento formó parte de un ciclo más extenso y debe relacionarse con otro

ranza Gigirey, y el conservador, D. Roberto Aneiros, la institución no posee depósito alguno procedente de la torre manriqueña.

${ }^{39}$ Los restos pictóricos de la torre son visibles tanto en el área sur de la estancia baja, entrando por la Buchería, como desde su costado norte, accesible desde el suelo de la capilla de San Fernando.

${ }^{40}$ Monterroso, Fernández 2006, p. 161; Carrero 1999, p. 344. 
resto, inédito hasta la fecha ${ }^{41}$, de un exquisito ángel que dirige su mirada a la izquierda, repitiendo las formas y técnica del querubín organista (fig. 6).

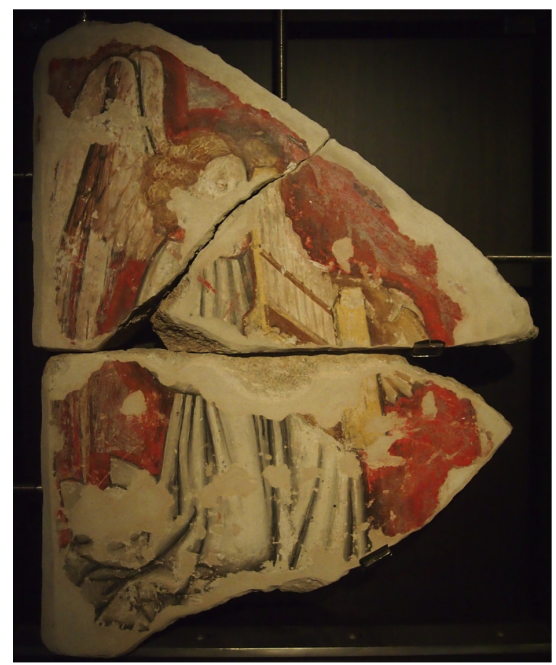

Fig. 5. Ángel con órgano, Museo de la catedral de Santiago. Foto del autor.
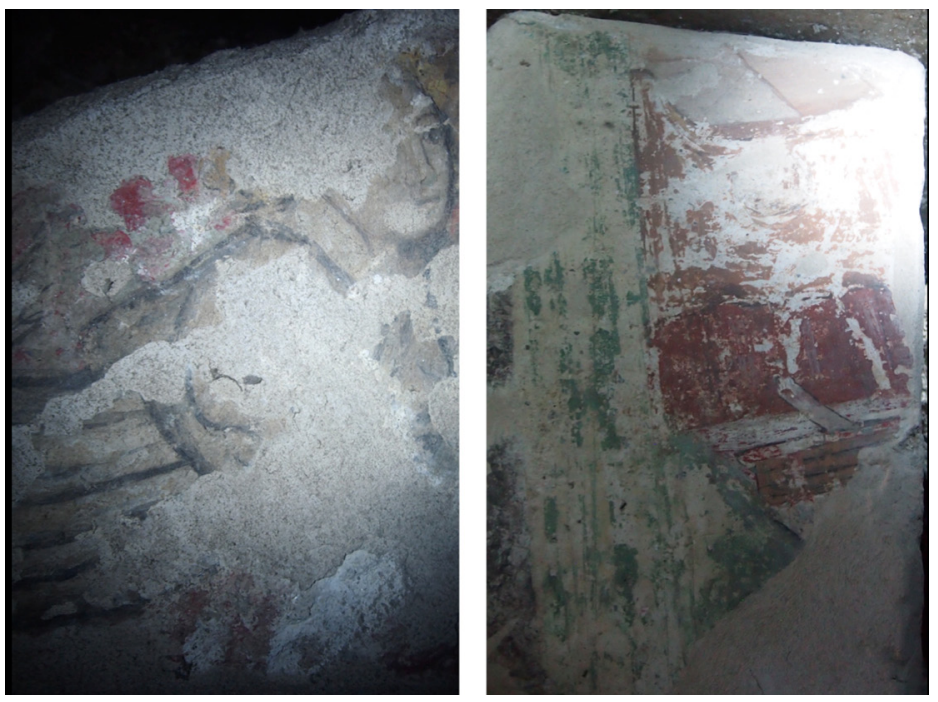

Fig. 6. Ángel y armarium, Museo de la catedral de Santiago. Fotos del autor.

${ }^{41}$ El 27 de octubre de 2018 se hallaba en la tribuna norte de la catedral. 
Consideramos que, por la calidad del dibujo, también el fragmento de enlucido desprendido de su sillar donde se representa un libro, junto a un armarium, pudo configurar una escena de coro angélico, quizás enmarcada por una alusión a la Jerusalén Celeste de la que restan fragmentos con microarquitecturas pintadas sobre algunos sillares desperdigados alrededor de la torre de Manrique. El más interesante, tampoco publicado, muestra una robusta torre con vanos de medio punto y saeteras en los mismos tonos grisáceos que la túnica del ángel organista. En el primer plano sobresale un pequeño templete con frontón decorado con retícula rojiza, con cubierta a dos aguas y cuyo entablamento apea sobre capiteles y columnas. Son edificios de sillares fingidos all'antica, en consonancia con los casetones antiquizantes que decoran la base de la torre y que enmarcarían la escena de los ángeles músicos sacralizando la apertura de las puertas de la Jerusalén Celeste (fig. 7).
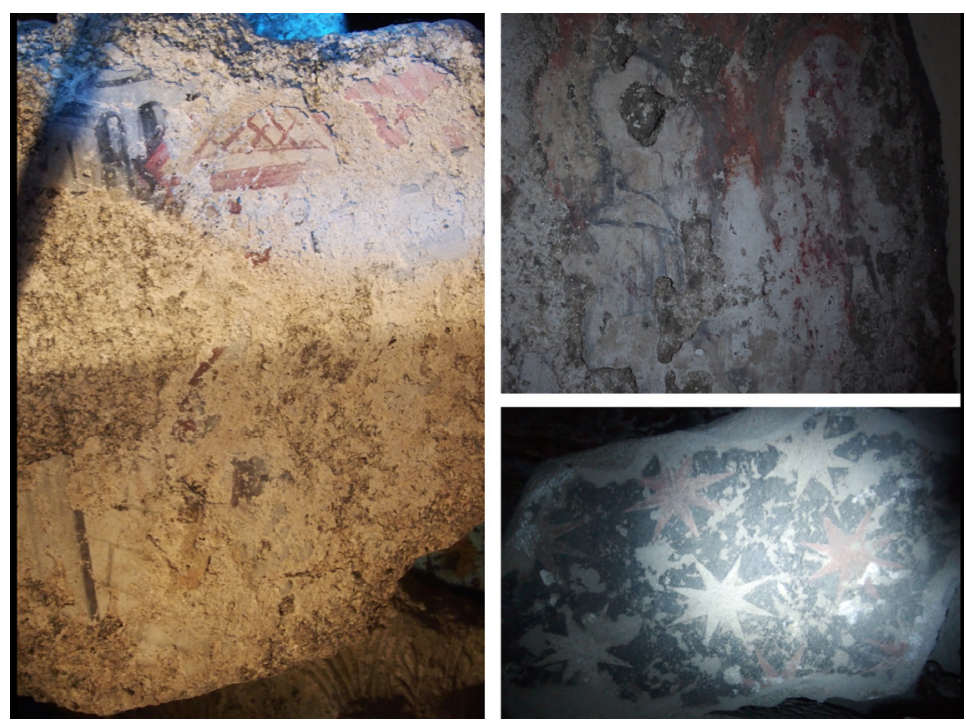

Fig. 7. Arquitecturas pintadas, Museo de la catedral de Santiago, Área Arqueológica de la Buchería. Ángel, Museo de las Peregrinaciones, Santiago de Compostela.

Fragmento de cielo estrellado, catedral de Santiago de Compostela. Fotos del autor.

El potente fondo rojizo de todos los murales es el mismo que el de otros restos pictóricos presentes en piezas desmembradas, pero que pertenecieron a los entornos de la torre y el claustro tardorrománico. Con cierta seguridad podemos defender que tanto el baluarte como algunas arquerías del claustro albergaron un ciclo pintado homogéneo. De hecho, la misma mano pintora se detecta en un fragmento conservado en el Museo de las Peregrinaciones 
y que muestra una figura angélica en el intradós de un arco de ese perdido claustro, acompañado de un diseño geométrico relacionable con el de la parte baja de la torre (fig. 7).

Del yacimiento arqueológico también procede un segmento de enfoscado donde se pintó un cielo estrellado con astros en blanco y rojo sobre fondo negro (fig. 7) ${ }^{42}$. Ello permite imaginar que, o la capilla funeraria o uno de los dos pisos superiores, se pintó con una visión de la bóveda astral, muy acorde con la imagen de la Jerusalén Celeste, aunque la destrucción del conjunto obliga a considerar todo ello como una hipótesis.

Estos fragmentos permiten afirmar que, dentro del corpus de la pintura gótica de Galicia, sin duda el ciclo del baluarte fue uno de los de mayor calidad. La pérdida de ejemplos no permite realizar aseveraciones pero los motivos descritos no fueron desconocidos entre los repertorios usados en el scriptorium compostelano. Aunque las épocas inciertas que vivió la ciudad no favorecieron la creación artística parece posible incluir la actividad de esos pintores murales en el marco de la reactivación de los talleres miniaturísticos de la catedral a mediados del siglo XIV y, más factiblemente, vincularla con el fenómeno de renovación pictórica del siglo XV y la llegada de corrientes flamencas mediante el llamado Breviario del canónigo Miranda (ca. 1470) ${ }^{43}$.

Aunque Gómez Manrique no vio concluidas las partes altas de su torre, su capilla estaba finalizada cuando fue promocionado a Toledo. La mención documental de 1354 a los pedreros y la escritura de fundación de 1361 nos ofrece un arco temporal de ocho años en los que la primera fase del baluarte pudo terminarse, pintarse con los casetones analizados y ornarse con esculturas.

En el tránsito por el claustro medieval, los canónigos advertirían la presencia de dos soldados graníticos, flanqueando el acceso a su capilla funeraria. El oriental sólo conserva el remate del faldellín, de pliegues rectos y el otro guerrero adosa los pies al muro mientras que el bloque en el que se labró

${ }^{42} \mathrm{El}$ análisis de pigmentos demuestra que ese color oscuro es el mismo que se utilizó en los casetones del zócalo de la capilla funeraria. El color rojo de los fondos es semejante al de los restos custodiados en el Museo de la Catedral, en el de las Peregrinaciones y los vestigios de la Buchería. El ciclo fue extenso y se extendió fuera de la torre, quizás en las arcadas claustrales que daban acceso al espacio mortuorio.

${ }^{43}$ Archivo de la Catedral de Santiago de Compostela, Ms. 3. En época del arzobispo Berenguel de Landoria (1330) se reactivó el scriptorium compostelano. El Breviario de Miranda se ha relacionado con el círculo de Jorge Inglés y Juan de Carrión, aunque la obra compostelana es de menor calidad: Yzquierdo 2012, p. 144. En todo caso, el fragmento de mural con el ángel organista parece igualmente vinculado a esta tradición flamenca. Por otra parte, la copia del Codex Calixtino conservada en la Biblioteca de la Universidad de Salamanca (Ms. 2361, f. 90r.) muestra un tipo de retícula similar en el fondo de la estancia donde el Apóstol se aparece a Carlomagno. En esa página se observan despieces de sillares, almenas y pequeños edificios semejantes a los motivos pictóricos de la torre. Sobre el manuscrito, véase: Villaseñor 2012. 
su cuerpo hoy está el Museo catedralicio (fig. 8). La unión de las dos piezas ofrece una figura de tamaño natural, que porta una lanza en la mano derecha y en la otra sujeta una espada y un escudo con las armas de los Manrique, las dos calderas jaqueladas con serpientes. Es muy probable que estas efigies estuviesen pintadas, matizando las formas rudas de ascendencia tardorrománica con las que trabajan estos escultores (fig. 8).
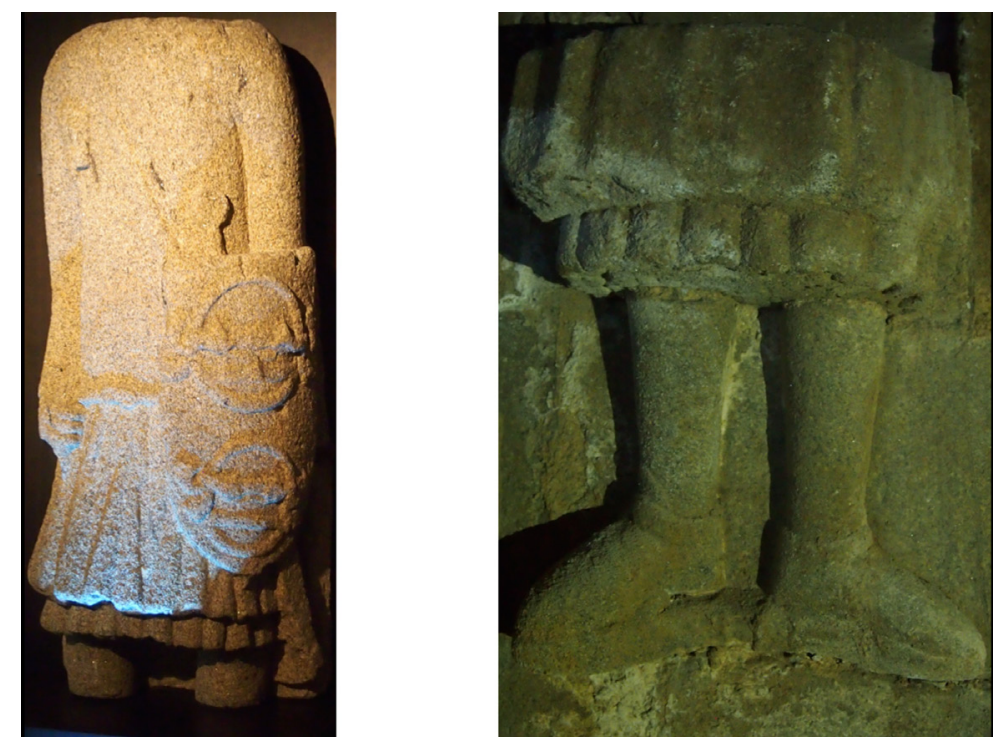

Fig. 8. Soldados procedentes de la torre de don Gómez Manrique, Museo de la catedral de Santiago y Área Arqueológica de la Buchería. Fotos del autor.

En el suelo de la capilla hoy yacen, descontextualizados, dos felinos labrados en sendos bloques (fig. 9) ${ }^{44}$. El análisis de los sillares ubicados bajo los pies del guerrero derecho no muestra muesca ni movimiento de paramentos que permita afirmar que bajo los soldados se ubicaron estos apeos leoninos. Al contrario, por la medida de las piezas, la longitud existente entre la cabeza y los cuartos traseros de los animales, parece probable que estemos ante los soportes dispuestos para elevar el sepulcro del arzobispo Manrique, solución habitual en la escultura funeraria de los siglos XIII y XIV. Muy factiblemente, tras su promoción toledana, éstos quedaron dispuestos en el suelo de la capilla a la espera de recibir un sepulcro que jamás llegó.

\footnotetext{
${ }^{44}$ Carrero 1997-1998, p. 43 indica que uno de los guerreros tiene "un león a sus pies", que nosotros no hemos visto en las visitas a la Buchería de los años 2018 y 2019.
} 

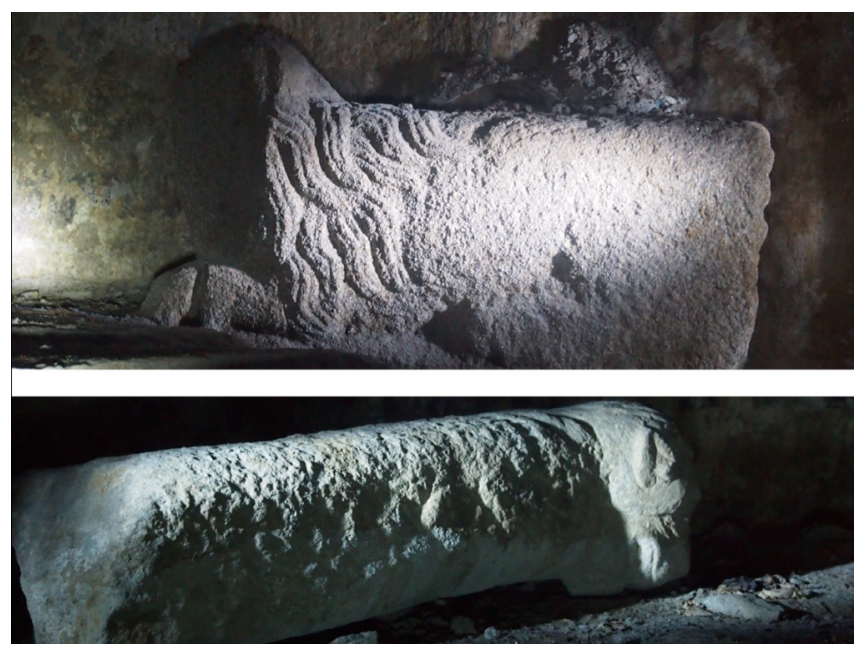

Fig. 9. Felinos (¿base del sepulcro de don Gómez Manrique?), Museo de la catedral de Santiago, Área Arqueológica de la Buchería. Fotos del autor.

Los escultores al servicio del prelado de nuevo están más cercanos a las formas de los rudos ornamentos de la arquitectura defensiva que a la renovación escultórica que el foco compostelano vivió a mediados del siglo XIV ${ }^{45}$.

Gómez Manrique levantó su gran torre en una época de crisis, bélica y de inseguridad para el cabildo, un baluarte terrenal que dio un nuevo amparo al tesoro - antaño atacado por la turba ciudadana- $y$, además, una torre funeraria, un monumento a su memoria protegido por guerreros que amenazarían a los que accediesen a su bastión desde el claustro, mostrando la fortaleza de la familia y su blasón. Acabada su capilla promocionó a Toledo y el proyecto fue abandonado hasta su conclusión durante el mandato de Juan García Manrique, su sobrino.

Sin embargo, no fue la única empresa arquitectónica que don Gómez inició. El área del palacio arzobispal, que remontaba sus orígenes al obispo Gelmírez y había recibido la gran reforma patrocinada por Juan Arias, también sufrió cambios durante los siglos XIII y XIV. A la bella estructura de dos pisos, con elegantes apeos en la planta baja y el despliegue de bóvedas con nervios y ménsulas cargadas de imágenes arriba, se añadió, en época posterior, una nueva ala, que se extendía longitudinalmente hacia el transepto norte de la catedral (fig. 10).

\footnotetext{
${ }^{45}$ Formas más elegantes presentes, por ejemplo, en el llamado tímpano de la capilla de doña Leonor del Museo catedralicio.
} 


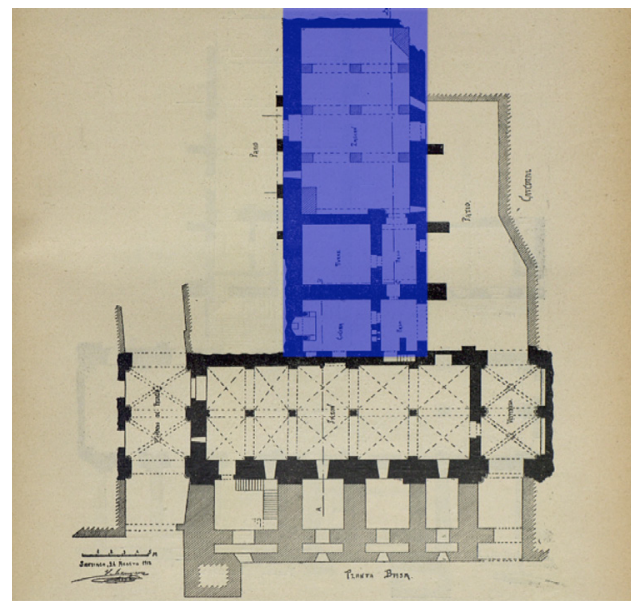

Fig. 10. Planta del palacio episcopal, ampliación de los Manrique, Santiago de Compostela. Plano de Vicente Lampérez y Romea (1913).

Ese nuevo y simple espacio, de paramentos y composición arquitectónica diferente a la fase anterior de Arias, está compuesto por dos naves de cuatro tramos, con arcos apuntados, que se repiten arriba, generando dos pisos. La tradición denomina este espacio "sala de Manrique" pero, sin documentación conocida, resulta difícil ofrecer datos incontestables (fig. 11).

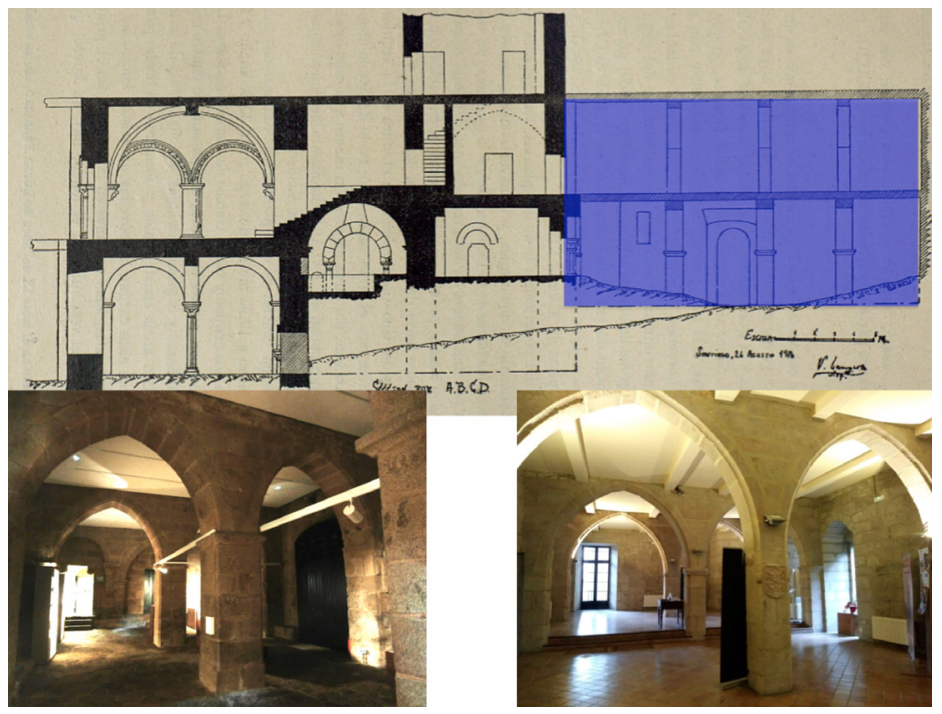

Fig. 11. Sección, piso bajo y superior del palacio episcopal, Santiago de Compostela. Plano de Vicente Lampérez y Romea (1913). Fotos del autor y R. Yzquierdo Peiró. 
No obstante, las armas familiares se labraron sobre uno de los pilares del segundo piso vinculando el proyecto al mecenazgo dinástico. Dos calderas y doce sierpes repiten en el palacio los motivos que ponían su sello a la capilla funeraria. López Ferreiro ya llamó la atención sobre la heráldica indicando que los escudos de armas -en plural- esculpidos:

no podemos atribuir fijamente tales obras al arzobispo D. Juan; porque dichos escudos eran también propios de su tío (...) es de observar que en los de la planta baja se observa mayor esmero y corrección que en los otros. De aquí pueda inferirse, que esta parte se hizo en el tiempo del Arzobispo D. Gómez (fig. 12) ${ }^{46}$.

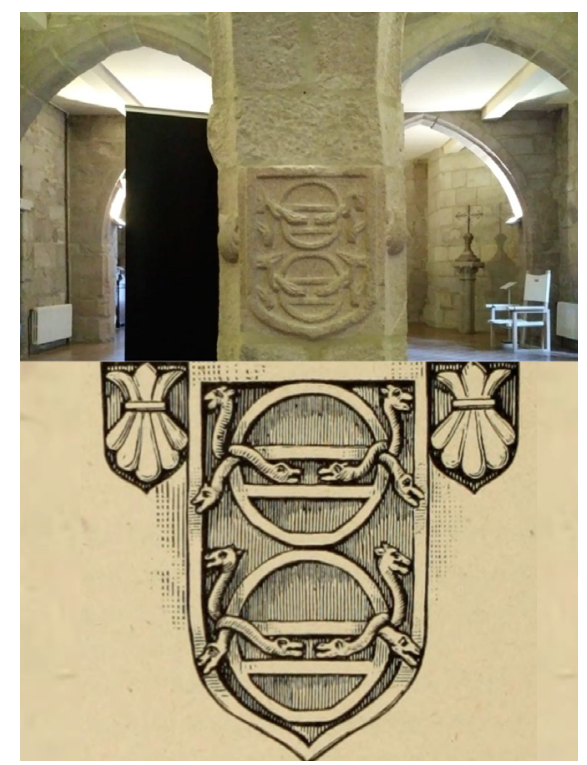

Fig. 12. Escudo de los Manrique, palacio episcopal, Santiago de Compostela.

Foto de R. Yzquierdo Peiró y dibujo de A. López Ferreiro (1903).

Nosotros no podemos ir tan lejos. En el segundo nivel se localiza el único escudo que hemos documentado y que podría demostrar la continuidad de unas obras que, iniciadas por el tío, fueron terminadas por don Juan. Al examinar los muros de ese ala se confirma cierta unicidad, la continuidad de la obra, lo que hace difícil poder diferenciar las fases ejecutadas por ambos prelados. Posiblemente pudo tratarse de artífices y talleres que pasaron del tío

\footnotetext{
${ }^{46}$ López 1903, vol. VI, p. 266, n. 2.
} 
al sobrino, aunque el primer piso posee una resolución de los arcos más ruda que los de la planta superior, de pilares más esbeltos ${ }^{47}$.

El arzobispo Juan García Manrique reunió al cabildo el 11 de agosto de 1385 en la torre que su tío había iniciado, decretando varios estatutos para la custodia de vasos sagrados, ornamentos y, además, el culto de la cabeza de Santiago Alfeo, regalo de doña Urraca al obispo Gelmírez ${ }^{48}$. Ordenó, además, que la preciada reliquia únicamente saliese del tesoro para procesionar por el claustro, noticia que remarca el valor escenográfico del baluarte en la topografía claustral. Posiblemente en estos momentos se acometieron las labores pictóricas antes descritas con la iconografía angelical.

Ya ocupando la cátedra toledana, e incluso una vez fallecido, la memoria de don Gómez en la catedral gallega se perpetuó mediante las obras de su sobrino, quien dio propiedades para costear esculturas de plata para la entrada del coro y paños ${ }^{49}$. El cabildo, ante las dádivas, dispuso el 24 de septiembre de 1384 que se celebrasen anualmente tres aniversarios por su alma, la de su antecesor D. Gómez y las de sus parientes y consanguíneos ${ }^{50}$. Don Juan respondió con nuevas donaciones: dos arcas de marfil para reliquias, un paño de oro imperial laurado a leturas moriscas, un manípulo ${ }^{51}$ y 30 anillos de oro, un camafeo y plata con piedras preciosas, entre las que destacaban algunas con cabezas de serpientes -piezas a las que dio gran valor por la vinculación de los ofidios con las armas familiares-. Todo fue depositado en 1396 en una arqueta ebúrnea que se custodió en el tesoro.

La desmochada torre manriqueña se remató con un tercer piso donde se ubicó la librería capitular, enriquecida con

una copia del Apocalipsis, dádiva de don Juan, en pergamino con pinturas pintadas para que senpre steuese eno dito thesouro pregado et fechado con cadeas de ferro et con fechadura en tal maneira que fosee ben gardado.

Este empuje dado a la librería propició otras donaciones en las décadas siguientes hasta su conclusión definitiva en $1454^{52}$.

\footnotetext{
${ }^{47}$ Cosmen, Moráis 2021.

${ }^{48}$ López 1903, vol. VI, p. 249. Se ratifican algunas normas sobre la protección del tesoro realizadas por el arzobispo don Berenguel de Landoira en 1325: Carrero 1997-1998, p. 44.

${ }^{49}$ López 1903, vol. VI, pp. 253-257.

${ }^{50}$ Ibidem, p. 261, Tumbo B, f. 284: González 2004.

${ }^{51}$ Ibidem, p. 263.

${ }^{52}$ Carrero 1997-1998, pp. 45-46.
} 


\section{TOLEDO}

En su Historia de Toledo (1862), Antonio Martín Gamero indicó que Gómez Manrique fue electo para la sede toledana aún siendo arzobispo en Compostela, incluso antes de morir su predecesor. En el testamento del rey Pedro I de 18 de noviembre de 1362 -monarca que siempre había mostrado su bienquerencia hacia el prelado-, se intitula a don Gómez como arzobispo de la sede primada. Así, tras la muerte de don Vasco, en un documento del 6 de febrero de 1363, don Gómez firma como electus toletanus, lo que ha llevado a suponer que, aún en esta fecha, no había recibido confirmación.

Según Konrad Eubel su promoción a Toledo se produjo el día 2 de mayo de 1362, cuando fue nombrado por Inocencio $\mathrm{VI}^{53}$.

Desde la historiografía decimonónica y hasta las investigaciones actuales se destacó el incremento de la actividad política de don Gómez ya desde la cátedra toledana, tomando partido en la guerra civil del rey de Castilla con el conde Trastámara y negando, desde los inicios de los años sesenta del siglo XIV, su apoyo al monarca legítimo, apartándose de su bando tras diez años de fidelidad a un rey que iba siendo abandonado paulatinamente ${ }^{54}$. Los estudios de Ana Arranz han analizado el intervencionismo papal y regio en la sede toledana y es en este marco donde se comprende la designación de don Gómez.

La elección del prelado abrió una brecha entre el arzobispado de Toledo y Pedro I, recrudeciéndose el enfrentamiento entre el papa y el rey, contrario a la política centralista realizada desde Aviñón. Desde su llegada a la mitra toledana las líneas seguidas por don Gómez fueron contrarias a los designios del rey, produciéndose la ruptura entre ambos. El conde de Trastámara aprovecharía esta coyuntura, apoyando a don Gómez y al cabildo, claves en el ascenso al trono castellano en 1369.

Así, ya en 1361 Enrique II otorgó y confirmó privilegios al arzobispo, lo que prueba el abandono del bando legitimista en los últimos meses de 1362. Los agradecimientos del nuevo rey se documentan a partir de 1369, estrechándose su relación hasta el punto que la Crónica de Ayala llegó a situar al arzobispo junto al monarca en plena guerra ${ }^{55}$.

En este contexto se explica la donación del señorío de Illescas que el nuevo rey realizó al arzobispo y al cabildo remarcando la lealtad de fiança del prelado $^{56}$. Días después Enrique II fue aún más dadivoso y dio a don Gómez

\footnotetext{
${ }^{53}$ Eubel 1913, vol. I, p. 487.

${ }^{54}$ Martín 1862, pp. 882-883; Arranz 1988; Villarroel 2013, p. 319.

${ }^{55}$ Chelle 2018, p. 43.

${ }^{56}$ García 1982, doc. 1 dado en Toledo el 8/6/1369.
} 
el señorío pleno y jurisdicción de esta villa por el seruicio que nos fezistes en nos ayudar a rreynar ${ }^{57}$.

Aunque la crisis que vivía la ciudad de Toledo en esos años no propiciaba acometer grandes proyectos en la fábrica catedralicia, don Gómez estaba familiarizado con estas situaciones desde sus días en Galicia.

El prelado aún vivió las consecuencias de sucesos precedentes, cuando en 1355 las tropas de Enrique de Trastámara asaltaron la judería de Toledo y asesinaron a un grupo de hebreos ${ }^{58}$. Así, el 11 de mayo de 1366, en plena guerra civil ${ }^{59}$, el conde de Trastámara dio Ordenamiento a Toledo, cuando los judíos tomaron parte por Pedro I, y entregó al arzobispo entre otros bienes, 8000 maravedies que pagaban los judios de Alcalá de Henares ${ }^{60}$. Además de ello, en la petición 31 del citado documento el soberano encargó al arzobispo acometer obras de envergadura en la cerca judía toledana: que vea toda la dicha cerca e faga et mande faser en ella aquellos portillos que el entendiere que cumple a nuestro servicio ${ }^{61}$. Nuevamente la arquitectura defensiva, apropiada para unos escenarios en crisis, se desplegaba ante la mirada del prelado.

Además de esta perspectiva urbana, don Gómez no obvió su catedral. Si en Compostela los modelos del pasado y la consideración del legado artístico de don Juan Arias habían marcado su quehacer, ahora en Toledo la figura de don Vasco, su antecesor, no le fue indiferente. Blas Fernández se había ocupado -entre otras cosas- de la recopilación normativa vigente sobre el cabildo, su formación y su desempeño en tareas litúrgicas, obligándoles a leer y comprender los textos sagrados, a cantar en las celebraciones y expresarse elocuentemente a la hora de predicar sermones y homilías ${ }^{62}$.

Estos antecedentes legislativos y litúrgicos marcaron los primeros años de don Gómez en Toledo. Como es sabido, desde 1322 se había recomendado la celebración de concilios provinciales cada dos años y de sínodos anuales y sabemos que, entre 1323 y 1356, se realizaron en Toledo seis concilios y doce sínodos diocesanos pero, tras esta continuidad, la peste negra que asoló la ciudad en los años siguientes y, sobre todo, la guerra civil, rompieron esta costumbre durante veinte años. Sólo con Gómez Manrique se restableció el orden a partir de 1371, convocando entre 1372 y 1374 dos

${ }^{57}$ Ibidem, doc. 2, del 25/6/1369. Se remarca que es una "donaçion pura, para agora e para siempre (...) con sus aldeas e con todos sus términos poblados e por poblar, e con los castiellos e fortalezas".

${ }^{58}$ Monterreal 2015, p. 60.

${ }^{59}$ Valdeón 1966, pp. 60-66.

${ }^{60}$ León 1979, vol. II, doc. 540; Monterreal 2015, p. 61.

${ }^{61}$ León 1979, vol. II, p. 158; Díez 2001, p. 295.

${ }^{62}$ Lop 2009, p. 361. 
nuevas asambleas sinodales en Alcalá ${ }^{63}$, que conocemos por referencias indirectas, pero donde se trataron temas relacionados con el cobro del diezmo y la residencia de beneficiarios y capellanes en la diócesis ${ }^{64}$. Esta inmersión en la política y la legislación conciliar parecen ocupar todo el tiempo de nuestro prelado pues no he podido documentar en la catedral toledana grandes encargos artísticos.

Don Gómez respetaba la tradición. En Toledo, tras el fallecimiento en 1362 de don Vasco y su enterramiento en la entrada del coro catedralicio, frente al altar de prima y la escultura de la llamada Virgen Blanca, la decisión sobre el lugar para su último descanso varió. Los usos funerarios de este espacio de la catedral se remontaban al año 1288 cuando Gonzalo Pétrez -o Petrez Gudiel- ordenó ser enterrado frente al altar de la Virgen del coro ${ }^{65}$, pero al sobrevenirle la muerte en Roma el 11 de mayo de 1299 fue sepultado en Santa María Maggiore. Finalmente fue el arcediano Ferrán Martínez quién trasladó sus restos y cumplió su deseo en la primavera de $1301^{66}$, inaugurando este espacio privilegiado como área funeraria. Y aquí sería enterrado don Gómez Manrique al morir el 19 de diciembre de 1375, muy sabedor de lo codiciado del espacio, pues aún en 1365 alertaba que si el cabildo se negaba a autorizar su enterramiento en el coro, su cuerpo podría ubicarse en la capilla de San Ildefonso ${ }^{67}$. De lo que no existe duda es de que nuestro prelado buscó emular, con la elección de este espacio como lugar para su último descanso, la autoridad de sus antecesores más ilustres.

En 1857 Ramón Sixto Parro ya efectuó un completo análisis de este altar que presidió el espacio de enterramiento de nuestro prelado, estudiando las tres lápidas ubicadas a los pies de la Virgen, recuerdo de las sepulturas con estatuas yacentes, hasta que en 1539 las quitaron con ánimo de hacer otras nuevas (pues tal vez estarian muy estropeadas las antiguas) ${ }^{68}$. Estos bultos funerarios se sacaron del coro y se compró el alabastro para realizar otros nuevos aunque, finalmente, tan sólo se dejaron los epitaphia sepulcralia. Mientras, hacía una década don Gómez había rechazado enterrarse en el viejo coro compostelano por considerar que el

\footnotetext{
${ }^{63}$ Lop 2003, p. 291.

${ }^{64}$ Sánchez 1976; Lop 2003, p. 291, nota 8, sínodo reunido en Alcalá el 08/06/1372.

${ }^{65}$ Murió el 16 de enero de 1288. Véase: Herráez, Teijeira 2018, p. 5, n. 27. Sobre el personaje: Hernández, Linehan 2004.

${ }^{66}$ Martínez 2010, p. 158.

${ }^{67}$ Nickson 2015, p. 101. Cita el autor la documentación de la Biblioteca Capitular de Toledo, 23-17, ff. 23r-25r, Real Academia de la Historia (Madrid), Fondo Salazar y Castro N-43, f. 54, del 20 de enero de 1357 y Archivo Capitular de Toledo, doc. A.5.A1.12, 15-16 del 24 de enero de 1365.

${ }^{68}$ Parro 1875, p. 160.
} 
ledooiro no era un espacio a la altura de su dignidad episcopal; ahora, en Toledo, reposó para siempre al lado de don Gonzalo y D. Vasco Fernández de Toledo.

Sobre esta cuestión el genealogista Luis Salazar y Castro aportó noticias poco analizadas hasta ahora, indicando que en el choro de la Santa iglesia de Toledo a los pies del altar de Santa María la Blanca ay tres losas debajo de las que las cuales están sepultados tres arzobispos en esta forma. Salazar dibujó las tres lápidas de Gometius Manrique, Gudisalbus Barroso y las armas de Blascus de Toledo, que se gastaron pisándolas (fig. 13) ${ }^{69}$. Éstas, como es sabido, se dispusieron a los pies del altare beate Marie in choro ecclesie tolletane $e^{70}$, donde se decían las misas de prima cantadas los sábados después de finalizar esa hora canónica y las de réquiem de difuntos, una vez al mes y con responso cantado por los prebendados que, antes, habían bajado al plano del coro $^{71}$.

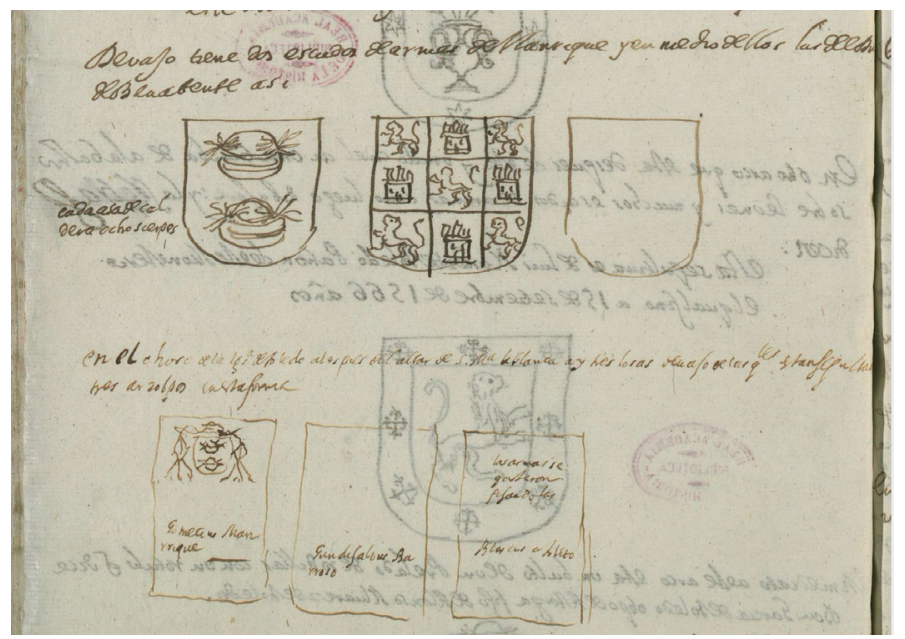

Fig. 13. Losa sepulcral de don Gómez Manrique, catedral de Toledo.

Dibujo de Salazar y Castro, Madrid, Real Academia de la Historia, sign. 9/292, f. 48.

Las fuentes revelan que, aunque existían otros altares de prima en la catedral con su liturgia propia, fue don Gómez el primero de los arzobispos en dotarla espléndidamente. Especifican los documentos que debían

\footnotetext{
${ }^{69}$ Real Academia de la Historia (Madrid), signatura 9/292, f. 48. La mención del arzobispo Barroso es un error y posiblemente quisiera referirse a don Gonzalo Pétrez.

${ }^{70}$ Herráez, Teijeira 2018, n. 69.

${ }^{71}$ Parro 1875, p. 171.
} 
acompañarse de órgano. El prelado dotó también otras cuatro memorias: a la noche, antes de iniciar los maitines, cantando la antífona Ave Regina Coelorum y la oración Concede nos. En segundo lugar, instauró que los viernes, excepto en cuaresma, se cantase la antífona Salve Regina. Los sábados por la mañana, tras la prima, el canto de la Salve y la oración Famulorum tuorum. Finalmente, en cuarto lugar, en los días que se rezaba de feria, ordenó que se cantase un responso tras la prima, otro tras finalizar nona, otro tras las vísperas y otro concluyendo completas. En conclusión: estos datos vuelven a confirmar la relevancia que el arzobispo dio a la liturgia y a la dotación musical de su espacio de enterramiento, al igual que había sucedido en Santiago. El recuerdo de su antigua sede y el culto al Apóstol debieron continuar vigentes desde Toledo pues la documentación informa sobre otro encargo artístico del arzobispo:

Item otra ymagen de Santiago de plata sobredorada de grand peso que dio el Arçobispo don Gomez. Dizese que se desizo e se fizo otro mayor el qual entre las otras cosas que dizen que el arçobispo saco quando lo de (...) leuo esta imagen ${ }^{72}$.

El patronazgo directo del prelado en la catedral fue limitado, aunque la proyección artística de su linaje permaneció en el tiempo: En la Santa iglesia de Toledo en un poste que está entre las capillas de los Reyes Viejos (y S. Lucía), ai un altar que tiene dos tablas una debajo del otra y ambas cubiertas con una corona.

El documento concreta que en la tabla superior estaba pintada Nuestra Señora y el niño en los brazos y en el inferior está San Benito y a su lado $S$. Bernardo y al izquierdo S. Gerónimo. Debajo de cada tabla ai escudos así. Además, se incluye el diseño de tres escudos, entre ellos, a la derecha, uno con calderas de color azul o verde, banderolas en azul, sin duda heráldica de la casa de los Manrique ${ }^{73}$.

La fuente remarca, finalmente, que

en el frontal que es de piedra dice en letras góticas. Este altar mandó facer el Señor Gómez Manrique. Debajo tiene dos escudos de armas de Manrique y en el medio de ellos las del dicho (conde?) de Benavente así.

\footnotetext{
${ }^{72}$ Archivo de la Catedral de Toledo, doc. X. 12. B. 1. 17a.

${ }^{73}$ Real Academia de la Historia (Madrid), signatura 9/292, f. 48. Es el mismo escudo que se halla en el monasterio de las Clarisas de Villamuriel de Cerrato (Palencia), en el refectorio del monasterio, ligado al patronazgo de la familia Manrique.
} 
Ciertamente Salazar y Castro dibujó las armas, con las calderas y ocho sierpes ${ }^{74}$. Aunque la heráldica vuelve a remarcar la importancia de la memoria familiar, todo parece indicar que esta obra fue comandada por otro Gómez Manrique, quizás el Señor de Villazopeque (1412-1490), nieto del Duque de Benavente, ya en el siglo $\mathrm{XV}^{75}$.

\section{GuAdAlajara y Nuestra SEÑORA DE SOPETRÁN}

Los nuevos proyectos artísticos y la labor comitente del arzobispo se enfocaron lejos de la catedral primada.

El arruinado monasterio de Nuestra Señora de Sopetrán (Torre del Burgo, Hita, Guadalajara) fue su principal objetivo. Por diferentes vías conocemos la documentación del siglo XIV relativa al enclave. Primeramente, a través de un documento conservado en el Archivo Histórico Nacional que lleva por título Relación Breve de la fundación del monasterio de Nuestra Señora de Sopetrán ${ }^{76}$ y que se puso por escrito en torno al 1600 . Un contenido similar presenta otro legajo conservado en el monasterio de Santo Domingo de Silos, pero procedente de San Benito de Valladolid. La documentación fue redactada alrededor de $1642^{77}$.

A estas dos fuentes debemos sumar las obras escritas por Sigüenza $(1606)^{78}$, Arce (1615) y Heredia (1679) ${ }^{79}$. Este último autor, que aún pudo ver mucha de la documentación original in situ, tituló el capítulo II de su obra En que se pone la Vida del Ilustrissimo Señor Don Gomez Manrique, (...) Fundador del Convento de Nuestra Señora de Sopetrán, considerándolo bienhechor del monasterio ${ }^{80}$.

El erudito estudió la carta de fundación del cenobio - contenida también en la documentación silense ${ }^{81}$ - con fecha de 27 de junio del año

\footnotetext{
${ }^{74}$ Ibidem. Por la cronología consideramos que junto al armas manriqueñas se colocaron las de Fadrique de Castilla (1360-1394), hijo del rey Enrique II y luego I Duque de Benavente a partir de 1378.

${ }^{75}$ Salazar 1697, p. 545. Este altar lo vio en el siglo XVI Ortiz 1546, ff. 198-199: "Cerca de aquí (se refiere a la capilla de los reyes viejos) está el altar de la Virgen llamada de la Consolación, el cual está pegado a la pila, quele erigio D. Gómez Manrique" y relata los milagros que allí sucedieron.

${ }^{76}$ Archivo Histórico Nacional (Madrid), Sección Osuna, leg. 1671-1. Editado por Carrasco 1997.

${ }^{77}$ Zaragoza 1976, p. 29.

${ }^{78}$ Sigüenza 1595-1605, vol. I.

${ }^{79}$ Heredia 1679.

${ }^{80}$ El capítulo III se titula "Como en el santuario de N. Señora de Sopetran se fundó monasterio de Monges de la orden de Nuestro Padre San Benito, por el ilustrisimo señor Don Gomez Manrique, arçobispo de Toledo": Heredia 1679, p. 108.

${ }^{81}$ Zaragoza 1976, p. 33.
} 
1372, actuando García de Pedro como notario y redactada en un pergamino grande:

Poseyeron esta cassa asta el año 1372 a 27 de junio, que el Sr. D. Gómez Manrique, arçobispo de Toledo a quien estavan sugetos los canónigos, los quitó y puso en su lugar monges de sant Benito que trujo de S. Millán de la Cogolla, fundando esta cassa en monasterio del Orden de san Benito como consta por esta escriptura de fundaçión ${ }^{82}$.

En este documento Gomerius divina misseratione Archiepiscopus Toletanus actúa como patrocinador de la nueva iglesia consagrada a Santa María: constituimus et edificamus, con el apoyo y consenso del capitulo toledano, dotando a la casa de bienes y posesiones a través de las rentas de la iglesia toledana. Fue así como la regla agustiniana dejó paso a la benedictina, con doce monjes con su abad Martín ${ }^{83}$.

Gomez Manrique fue dadivoso para acometer esta refundación

y les dio para su sustento las tercias de Trijueque, Muduex, y Valdearenas (...) todo lo cual reza la bula de fundación y de su patrimonio trocó la villa de Aljofin que es a tres leguas de Toledo, con la de Medianelo (...) que era de su patrimonio ${ }^{84}$,

entregándoles, además trescientas ouejas, 50 vacas y 8 pares de bueyes (...) 50 mil maravedies ${ }^{85}$.

Para la empresa el arzobispo contó, de nuevo, con el apoyo real pues sabemos que los monjes compraron heredades y tierras con dinero que para ello les dio el dicho Señor Arzobispo y los 20 escusados que dio por privilegio a esta casa a petición suya el rey don Enrique, según reza el privilegio dado en Burgos por Enrique II dos meses después de la refundación del monasterio ${ }^{86}$.

¿Se tradujeron estos favores y peculios en la fábrica de Nuestra Señora de Sopetrán y sus bienes artísticos? Nada sabemos. Los posibles orígenes altomedievales del enclave son oscuros y las últimas campañas de excavación buscaron el edificio que auia edificado el señor Rey D. Alonso el Sexto, con lo que estaua començado a fabricar de la nueva ${ }^{87}$. Sin datos concluyentes,

\footnotetext{
${ }^{82}$ Ibidem.

${ }^{83}$ Carrasco 1997. En esta fuente, no obstante, se indica que la comunidad procedente de San Millán de la Cogolla entró en la casa el 1 de septiembre de 1374.

${ }^{84}$ Carrasco 1997. Todas las localidades están en Guadalajara.

${ }^{85}$ Zaragoza 1976, n. 14.

${ }^{86}$ Ibidem, p. 35.

${ }^{87}$ Argaiz 1675, pp. 137-138.
} 
los arqueólogos detectaron posibles restos de este edificio del siglo $X$, bajo el claustro clasicista de Sopetrán ${ }^{88}$.

Las profundas remodelaciones acometidas a lo largo de su historia en la iglesia y sus claustros fueron especialmente importantes en tiempos de Íñigo López de Mendoza y la marquesa Catalina de Figueroa durante el siglo $\mathrm{XV}$. Tras estas renovaciones no conservamos rastro alguno entre las actuales ruinas de estructuras atribuibles a don Gómez. No obstante Enrique Lafuente Ferrari aún documentó restos

mudéjares (...) con arquillos de herradura lobulados, como los que aún se ven hacia el lado de la epístola de lo que fue iglesia, acaso dejados al descubierto por la ruina de ésta. Sería esta parte la edificada, quizá, para la primera fundación del siglo XIV, la del Arzobispo D. Gómez ${ }^{89}$.

De todas estas obras que patrocinó nuestro prelado, si damos crédito a las palabras de Heredia, no quiso que en la iglesia ni en otra parte se pusiessen sus armas $^{90}$. El dato, de ser cierto, revela una actitud bien diferente a la que había mostrado en Compostela, donde selló con su escudo las empresas que había comandado.

Sin embargo, lo que si aclaran las fuentes es la largueza del arzobispo en la dotación de misas y altares:

mandando que perpetuamente, por él y por sus difuntos, se dijesen en la capilla de Nuestra Señora, cada día una misa, de suerte que la renta que dejó el arzobispo con los curatos, vale hoy día a la casa, en cada año, más de tres mil ducados ${ }^{91}$.

La memoria de don Gómez perduró en el monasterio que había refundado durante siglos. Arce informó sobre una capilla donde se ubicaba la imagen de la Virgen, adornada con lámparas, cadenas, mortajas, ataúdes, insignias, con una rexa de hierro dorada y plateada: al cabo de la Capilla grande ay una tribuna donde cada día se dize una missa cantada de nuestra Señora por el arçobispo don Gómez Manrique ${ }^{92}$. Es la misma construcción que el documento del Archivo Histórico Nacional describe como capilla pequeña, donde está la santísima

88 "Obras de cal y canto y de ladrillo que tal vez pudieran ser las del tiempo de Alfonso VI": Vela 2007; Vela, et al. 2008.

${ }^{89}$ Lafuente 1929 , p. 97 . Los arqueólogos han encontrado gran cantidad de material latericio en las prospecciones pero nada seguro podemos afirmar en este punto: Vela 2007, p. 691.

${ }^{90}$ Heredia 1676, pp. 107-108.

${ }^{91}$ Carrasco 1997.

${ }_{92}$ Arce 1615 , p. 83 
imagen como se ve por el edificio de ella, es antiquisimo, créese haber sido hecha en tiempo de don Gómez Manrique ${ }^{93}$. Nada queda hoy de todo ese pasado.

La reorganización y el apoyo al monasterio de Sopetrán que llevó a cabo el arzobispo debe comprenderse, una vez más, en el marco de una política continuista que persiguió recuperar la rectitud de la casa. El acta fundacional concretaba que los anteriores monjes se relajaron en la observancia regular lo que propició su intervención, transformando la vida clerical, en el marco de la profunda labor reformadora que se había iniciado en la diócesis de Toledo años antes con Gil Álvarez de Albornoz (1338-1350), y particularmente, a través del sínodo provincial de 1342 que finalizaría en Sopetrán ya en tiempos de la familia Mendoza ${ }^{94}$.

\section{SAN BARTOLOMÉ DE LUPIANA}

Antes de morir, don Gómez aún enfrentó su última gran empresa apoyando, entre 1370 y 1373, al monasterio de San Bartolomé de Lupiana (Guadalajara). Tanto los autores modernos, particularmente Fray José de Sigüenza ${ }^{95}$, como los más recientes, señalaron que se trata de la fundación jerónima más antigua de España ${ }^{96}$.

Sobre sus orígenes este autor indica que existía una ermita de Nuestra Señora de Villaescusa, cerca de Orusco, Madrid: en la ribera de río Taxuña, en aquella parte del arzobispado de Toledo (...) que se llama Alcarria (...) poco más de tres leguas de donde agora está el monasterio de San Bartolo$m e^{97}$, ocupada por los ermitaños Pedro Fernández Pecha y Fernando Yañez, junto con otros penitentes. Prosigue su narración indicando que el caballero Diego Martínez de la Cámara y su esposa, devotos de San Bartolomé, eligieron una ladera, en el lugar llamado Lupiana, para levantar una pequeña ermita dedicada al apóstol. Sigüenza no escatima en datos, pues los toma, indica, del testamento del caballero y de las escrituras originales de Martínez de la Cámara: Alli edificaron vna capilla para aquel tiempo, y para su intento harto grande (la misma que agora sirve al monasterio). En este templo de San Bartolomé de Lupiana ya fue enterrado el caballero en 1338 según el epitafio de su sepultura que esta en el macizo de la pared al lado de la Epístola98.

\footnotetext{
${ }^{93}$ Carrasco 1997, p. 40.

${ }^{94}$ Sánchez 1976, p. 46.

${ }^{95}$ Sigüenza 1595-1605, vol. I, p. 44.

${ }^{96}$ Lourine, et al., 1846, p. 48, n. 1; Zolle 1996.

${ }^{97}$ Sigüenza 1595-1605, vol. I, p. 16.

${ }^{98}$ Herrera 1974, p. 172.
} 
Ante la pobreza del templo de Villaescusa, la comunidad de eremitas decidió trasladarse a esta iglesia de Lupiana, contando con el apoyo de don Gómez Manrique ${ }^{99}$ : Era esto, según la mejor cuenta, el año de 1370 de nuestra redención y 38 después de la muerte de Diego Martínez de la Cámara, y tres antes de la confirmación de la Orden.

Para obtener confirmación de la orden jerónima y su establecimiento total en Lupiana, además de conseguir poderes para fundar otros enclaves, se decidió enviar a Aviñón a Pedro Fernández Pecha y Pedro Romano en 1373, solicitando al papa Gregorio XI la aprobación de la institución y poniendo como avales el apoyo del rey Enrique II y del arzobispo don Gómez Manri$q \mathrm{e}^{100}$. De hecho, el importante papel jugado por el prelado se especificó en la bula papal: es verdad que los ermitaños posseyan ya la dicha Iglesia de $S$. Bartolomé con las casas que junto a ella estauan por titulo y autoridad del Arçobispo de Toledo don Gómez Manrique ${ }^{101}$.

Finalmente, mediante la bula Sane Petitio de 18 de octubre de 1373 el papa Gregorio XI confirmó el establecimiento de la orden de San Jerónimo en los reinos de Castilla, León y Portugal, nombrando a Fernández Pecha primer prior del monasterio lupianense ${ }^{102}$, además de ordenar su vida bajo la regla de San Agustín, conforme al canon 13 del IV Concilio de Letrán, y las constituciones del monasterio de Santa María del Santo Sepulcro de Florencia, así como la facultad de fundar cuatro monasterios: San Jerónimo de Guisando, Santa María de la Sisla (ambos en 1374), San Jerónimo de Corral Rubio (1384) y San Jerónimo de Cobalta (1388) ${ }^{103}$.

Tras el regreso de los legados el día 1 de febrero de $1374^{104}$, el prior, con el apoyo de Gómez Manrique y las aportaciones de parte de las haciendas de Fernández de Pecha y sus parientes, se edificaron las celdas, 12 capillas para la misa, un cementerio en el medio día de la iglesia y un claustro, pobre de setenta pies de largo, de ancho onze con tres pandas, dexando descubierta la entrada del sol al mediodía y que la tradición denominó Claustro de los Santos.

Ese mismo año Pecha dejó vacante el priorato y fue sucedido por Fray Fernando Yáñez, quien solicitó en 1374 a don Gómez que consagrase la iglesia y el claustro:

\footnotetext{
${ }^{99}$ Llopis 1998, p. 430, n. 42.

${ }^{100}$ Sigüenza 1595-1605, vol. I, p. 28; Llopis 1998, p. 430.

${ }^{101}$ Sigüenza 1595-1605, vol. I, p. 32.

${ }^{102}$ Salazar 1697, p. 327.

${ }^{103}$ Vizuete 1992, p. 304. Se analiza la bula en: Madrid 1973, pp. 57-74; Revuelta 1982, p. 133; Sánchez 1976, p. 166; Llopis 1998, p. 430, n. 42.

${ }^{104}$ En el verano de ese año según Ruiz 1997, p. 17.
} 
hizo todas las santas cerimonias, que para aquel acto de bendición, y de dedicación se requieren en el claustro, y en la Iglesia: y con su autoridad quedo todo aquello consagrado al santo Apóstol, y con titulo de monasterio de la Orden de S. Gerónimo.

De nuevo las grandes reformas que sufrió el monasterio hicieron desaparecer todas las obras del siglo XIV y debemos conformarnos con aquello que las fuentes trasmiten. La largueza del promotor, don Gómez, se conmemoraba en un epígrafe, también perdido, que se extendía por el contorno del claustro, de la parte de dentro, en lo mas alto ${ }^{105} \mathrm{y}$ en el que se remarcaba el papel del prelado como constructor. En 1922 aún subsistía pero difícilmente puede ser descifrada, por hallarse bastante borrosa:

ESTE ES EL PRIMER CLAUSTRO EN EL QUAL FUE PRIMERAMENTE FUNDADA LA ORDEN DEL BIENAUENTURADO SAN GERÓNIMO EN ESPAÑA, POR EL MUY SANTO PADRE GREGORIO XI DE SANTA MEMORIA, EN EL AÑO DEL SEÑOR, MIL Y TREZIENTOS, Y SETENTA Y TRES AÑOS, A SUPLICACIÓN DE LOS VENERABLES PADRES F. PEDRO FERNANDEZ PECHA, E FRAY FERNANDO YAÑEZ DE CÁCERES, PRIMEROS FRATES DE LA DICHA ORDEN. RECIBIENDO EL NUESTRO HABITO DE LA MANO DEL SANTO PADRE. EL QUAL DICHO CLAUSTRO FUE EREGIDO EN MONASTERIO POR EL REUERENDO PADRE DON GÓMEZ MANRIQUE ARÇOBISPO DE TOLEDO EN EL SOBREDICHO AÑO ${ }^{106}$.

El día 19 de diciembre de 1375 moría en Toledo don Gómez Manrique, siendo enterrado a los pies del altar de prima en el coro catedralicio. La Crónica de Enrique II lo relata así:

Y en este año finó d. Gómez Manrique: y ovo en la iglesia muy gran contienda sobre la elección del arçobispo: que los unos querían que fuesse don Pedro Fernández Cabeça de Baca, que era dean en la iglesia de Toledo. E los otros querían a Don Juan García Manrique obispo que era de Orense, y sobrino del dicho arçobispo don Gómez Manrique, fijo de su hermano. Y el papa Gregorio que entonces era, dio el arçobispado de Toledo a D. Pero Tenorio, que era obispo de Coimbra, en Portugal ${ }^{107}$.

${ }^{105}$ Sigüenza 1595-1605, vol. I, p. 44.

${ }^{106}$ Ibidem, p. 44; Cordavias 1922, p. 23. Véase la ficha "AEHTAM 4186", Archivo Epigráfico de Hispania Tardoantigua y Medieval [en línea], http://hesperia.ucm.es/consulta_aehtam/ Texto.php?filtrar $=\&$ valor $=\&$ id $=4229$, [consulta: $27 / 04 / 2020]$.

${ }^{107}$ López de Ayala, Crónicas, p. 78. 
El repaso realizado al cursus honurum y el mecenazgo artístico del arzobispo Gómez Manrique permite extraer diversas conclusiones. En pleno siglo XIV, marcado por los ambientes de conflicto y crisis, el prelado supo adaptarse a las fábricas preexistentes donde comandó sus empresas. Sus gustos y preferencias en relación con la arquitectura, la escultura y la protección de los enclaves monásticos varió al compás de los escenarios que recorrió y los acontecimientos históricos.

El gran baluarte que proyectó en el claustro compostelano destacó por su originalidad, al incluir varios niveles y su capilla funeraria, protegida por las efigies de dos guerreros que ostentaban sus armas familiares. Los modelos defensivos y propios del arte gótico civil dominaron un proyecto respetuoso con la catedral románica y la topografía tumbal del claustro. Los datos aportados sobre el perdido ciclo pictórico que ornó ese espacio -elaborado en diferentes fases cronológicas- muestran la calidad de la obra. Por otra parte, la ampliación del palacio episcopal que llevó a cabo refleja la renovación de estructuras constructivas en épocas inciertas, documentándose la continuidad de proyectos y artífices trabajando, posiblemente, al servicio de su sobrino Juan García Manrique.

Finalmente, hemos analizado las consecuencias artísticas provocadas por su promoción a Toledo. En la primada sus gustos conservadores y preferencias cambiaron, tanto en la elección del lugar de enterramiento como en la refundación y reconstrucción de enclaves tan relevantes como los monasterios de Sopetrán y Lupiana. El patrocinio de diversas obras edilicias y escultóricas, su preocupación por la liturgia y la música de las sedes que ostentó, así como su activo papel político y de legislador eclesiástico demuestran la importancia de don Gómez Manrique.

\section{BIBLIOGRAFÍA CITADA}

Arce, Basilio de (1615), Historia del origen, fundación, progreso y milagros de la Casa y Monasterio de Nuestra Señora de Sopetrán, de la Orden de San Benito, Madrid, Viuda de Alonso Martín.

Argaiz, Gregorio de (1675), La soledad laureada por San Benito y sus hijos, vol. I, Madrid, Fernández de Buendía.

Arranz, Ana (1988), Un personaje y un episodio de la guerra civil castellana: el arzobispo D. Gómez Manríquez y el Ordenamiento de Toledo de 1366, "Anuario de estudios medievales" 18, pp. 309-322.

Arranz, Ana (2006), Titulación académica y promoción política de los obispos castellanos en tiempos de Pedro I, en Estudos em homenagem ao professor doutor José Marques, Porto, Universidade do Porto, pp. 165-176.

Carrasco, Jesús (1997), Relación Breve de la fundación del monasterio de Nuestra Señora de Sopetrán a la vista de un documento conservado 
en el Archivo Histórico Nacional: una puesta al día, "Wad-al-Hayara" 24, pp. 25-40.

Carrero, Eduardo (1997-1998), La Capilla de los Arzobispos, el Tesoro y la Torre de don Gómez Manrique en la catedral de Santiago de Compostela, "Anuario del Departamento de Historia y Teoría del Arte" 9-10, pp. 35-51.

Carrero, Eduardo (1999), Ángel músico. Restos de pintura mural procedentes de la Torre de don Gómez Manrique, en Santiago. La Esperanza, Santiago, Xunta de Galicia, pp. 344-345.

Carrero, Eduardo (2005), Las catedrales de Galicia durante la Edad Media. Claustros y entorno urbano, A Coruña, Fundación Barrié de la Maza.

Chamoso, Manuel (1971), Noticias sobre los recientes descubrimientos arqueológicos y artísticos efectuados en Santiago de Compostela, "Príncipe de Viana" 32, pp. 35-48.

Chelle Ortega, José (2018), Fuentes, estructura, ámbitos y lineas de interpretación en el estudio de las relaciones entre la Iglesia y la realeza castellana (1366-1390), "Incipit" 6, pp. 39-48.

Conant, Kenneth (1983), Arquitectura románica da Catedral de Santiago de Compostela, Santiago, Colexio de Arquitectos de Galicia.

Cordavias, Luis (1922), El Monasterio de Lupiana: antecedentes para su historia, Guadalajara, Gutenberg.

Cosmen Alonso, María Concepción; Moráis, José Alberto (2021), Gran palacio y sólidas torres: la comitencia artística de los arzobispos Gómez Manrique y Juan García Manrique en Santiago de Compostela, en Architettura per la vita. Palazzi e dimore dell'ultimo gotico tra XV e $X V I$ secolo (en prensa).

Díaz, Jorge (2005), La incorporación de la nobleza al alto clero en el reino de Castilla durante la Baja Edad Media, "Anuario de Estudios Medievales" $35 / 2$, pp. 557-603.

Díaz, Jorge (2006), Iglesia, nobleza y oligarquías urbanas, en Nieto Soria, José Manuel (ed.), La monarquía como conflicto en la corona castellano-leonesa (c. 1230-1504), Madrid, Sílex, pp. 197-252.

Díez, María (2001), El arte mudéjar. Expresión estética de una convivencia, Granada, Universidad de Granada.

Díaz y Díaz, Manuel Cecilio (1983), Hechos de don Berenguel de Landoira. Arzobispo de Santiago, Santiago, Universidad de Santiago de Compostela.

Eubel, Konrad (1913), Hierarchia catholica medii aevi, vol. I, Münster, Regensberg.

Flórez, Enrique (1767), España Sagrada, vol. XXII, Madrid, Antonio Marín. 
García, José (1982), Expansión del régimen señorial en la región de Toledo bajo Enrique II: Talavera de la reina e Illescas, "Anales toledanos" 14, pp. 75-93. González, María (2004), Tumbo B de la Catedral de Santiago, Santiago de Compostela, Ediciós do Castro.

Heredia, Antonio de (1676), Historia del Ilustrissimo Monasterio de Nuestra Señora de Sopetrán de la Orden de San Benito de su santuario y sagrada imagen, Madrid, Bernardo de Hervada.

Hernández, Francisco; Linehan, Peter (2004), The Mozarabic Cardinal. The Life and Times of Gonzalo Pérez Gudiel, Florencia, SISMEL Edizioni del Galluzzo.

Herráez, María Victoria; Teijeira, María Dolores (2018), Entre Castilla y Portugal. El patronazgo de Vasco Fernández de Toledo (†1362), "Journal of Medieval Iberian Studies" 10/3, pp. 341-363.

Herrera, Antonio (1974), Monasterios y conventos de Castilla-La Mancha, Guadalajara, Institución Provincial de Cultura Marqués de Santillana.

Lafuente, Enrique (1929), Las tablas de Sopetrán, "Boletín de la Sociedad Española de Excursiones" 37, pp. 89-111.

Lampérez, Vicente (1913), El antiguo Palacio Episcopal de Santiago de Compostela, Madrid, Hauser.

León, Pilar (1979), Judios de Toledo, Madrid, Consejo Superior de Investigaciones Científicas.

Llopis, Enrique (1998), Milagros, demandas y prosperidad. El monasterio Jerónimo de Guadalupe, 1389-1571, "Revista de Historia Económica" 2, pp. 419-451.

Lop, María José (2003), Legislación sinodal y cabildos catedralicios: el caso toledano (siglos XIV-XV)", en Abadia. IV Jornadas de Historia en la Abadía de Alcalá la Real, Jaén, Diputación Provincial, pp. 289-306.

Lop, María José (2009), La catedral de Toledo, ente generador de cultura a fines de la Edad Media, en Boucheron, Patrick; Ruiz, Francisco (coords.), Modelos culturales y normas sociales al final de la Edad Media, Cuenca, Ediciones de la Universidad de Castilla-La Mancha, pp. 357-386.

López, Antonio (1903), Historia de la Santa A. M. Iglesia de Santiago de Compostela, vol. VI, Santiago, Seminario Conciliar Central.

López, Antonio (1904), Historia de la Santa A. M. Iglesia de Santiago de Compostela, vol. VII, Santiago, Seminario Conciliar Central.

López de Ayala, Pedro, Crónicas de los Reyes de Castilla. Don Pedro, D. Enrique II, D. Juan I, D. Enrique III, ed. Eugenio de Llaguno, Madrid, Imprenta de D. Antonio de Sancha, 1779-1780.

Lourine, Louis; Brot, Alphonse; Rodríguez, Miguel (1846), Los conventos: obra filosófica y poética. Su origen, historia, reglas, disciplina, costumbres, tipos y misterios, Madrid, Madoz. 
Madrid, Ignacio de (1973), La bula fundacional de la orden de San Jerónimo, "Studia Hieronymiana" 1, pp. 57-74.

Martín, Antonio (1862), Historia de la ciudad de Toledo, Toledo, Imprenta de Severiano López.

Martínez, Balbina (2010), El linaje y las armas del arzobispo toledano Gonzalo Pétrez "Gudiel" (1280-1299), "Toletum" 57, pp. 131-169.

Monterreal, Óscar (2015), La judería de Toledo en la Edad Media: el arte en su entorno, Madrid, Universidad Complutense (tesis doctoral).

Monterroso, Juan; Fernández, Enrique (2006), A pintura mural nas catedrais galegas, Santiago de Compostela, Tórculo Edicións.

Nickson, Tom (2015), Toledo Cathedral: Building Histories in Medieval Castile, University Park, The Pennsylvania State University Press.

Nieto Soria, José Manuel (1993), Iglesia y génesis del estado moderno en Castilla (1369-1480), Madrid, Editorial Complutense.

Ortiz, Blas (1546), Descripción del sumo y máximo templo de la Santa Iglesia de Toledo y de todas las demás cosas que en él hay dignas de saberse, manuscrito conservado en Biblioteca Nacional (Madrid), Ms. 9168.

Otero, Ramón; Yzquierdo, Ramón (1990), El coro del Maestro Mateo, La Coruña, Barrié de la Maza.

Parro, Sixto Ramón (1875), Toledo en la mano o descripción histórico-artística de la magnifica catedral y de los demás célebres monumentos, vol. I, Toledo, Severiano López.

Puente, José (1985), La catedral gótica de Santiago de Compostela: un proyecto frustrado de D. Juan Arias (1238-1266), "Compostellanum" 30/3-4, pp. 245-276.

Revuelta, José (1982), Los Jerónimos. Una orden religiosa nacida en Guadalajara, Guadalajara, Institución Provincial de Cultura Marqués de Santillana.

Ruiz, José (1997), Los monasterios jerónimos españoles, Segovia, Caja Segovia.

Salazar y Castro, Luis de (1697), Historia genealógica de la casa de Lara, vol. III, Madrid, Imprenta Real.

Sánchez, José (1976), Concilios provinciales y Sínodos toledanos de los siglos XIV y XV la religiosidad cristiana del clero y pueblo, La Laguna, Universidad de La Laguna.

Sigüenza, José de (1595-1605), Historia de la orden de lo San Jerónimo, vol. I, Madrid, Bailly Baillière e Hijos.

Valdeón, Julio (1966), Enrique II de Castilla: la guerra civil y la consolidación del régimen, 1366-1371, Valladolid, Universidad de Valladolid.

Vázquez, Julio (1998), La Berenguela y la Torre del Reloj de la catedral de Santiago, "Semata" 10, pp. 111-148. 
Vázquez, Julio (2015), La fortaleza del apóstol Santiago. Imagen real e imaginario colectivo de la catedral de Santiago de Compostela en la Edad Media, "Codex Aquilarensis" 31, pp. 151-166.

Vela, Fernando (2007), Monasterio de Sopetrán (Hita, Guadalajara). Arqueología y construcción histórica, en Actas I Jornadas de Arqueología de Castilla-La Mancha, Cuenca, Universidad de Castilla-La Mancha, pp. 681-704.

Vela, Fernando; Daza, Enrique; Vega, Elena; Villafruela, Esther (2008), La construcción de la iglesia abacial del monasterio de Nuestra Señora de Sopetrán en Hita: aportaciones desde la arquitectura, en GarcíaSoto, Ernesto; García, Miguel; Martínez, Juan (coords.), Actas del Segundo Simposio de Arqueología de Guadalajara, Molina de Aragón, Centro de Profesores de Sigüenza, pp. 367-382.

Villarroel, Oscar (2013), Eclesiásticos en la negociación de la paz en la Castilla bajomedieval, en Arranz, Ana; Rábade, María; Villarroel, Óscar (coords.), Guerra y paz en la Edad Media, Madrid, Sílex, pp. 309-342.

Villaseñor, Fernando (2012), Iconografía del "Liber Sancti Jacobi" de la biblioteca histórica de la Universidad de Salamanca (MS. 2631): entre la tradición del "Jacobus" y la proyección posterior, "Ad limina" 3, pp. 181-210.

Vizuete, Juan (1992), La hospitalidad entre los jerónimos: monarcas y peregrinos, en Santiago, Horacio (coord.), El Camino de Santiago: la hospitalidad monástica y las peregrinaciones, Valladolid, Junta de Castilla y León, pp. 303-312.

Yzquierdo, Ramón (1989), Aproximación al estudio del claustro medieval de la catedral de Santiago, "Boletín de estudios del Seminario Fontán Sarmiento" 10, pp. 16-21.

Yzquierdo, Ramón (2012), La miniatura en Galicia en la Baja Edad Media, en Lacarra, María del Carmen (coord.), La miniatura y el grabado de la Baja Edad Media en los archivos españoles, Zaragoza, Institución Fernando el Católico, pp. 103-156.

Zaragoza, Ernesto (1976), Un abadologio inédito del monasterio de Sopetrán, "Wad-Al-Hayara" 3, pp. 27-46.

Zolle, Luis (1996), El monasterio de San Bartolomé de Lupiana. Precisiones en torno a su construcción: 1504-1612, "Archivo Español de Arte" 69 , pp. 269-285.

Fecha de recepción del artículo: julio 2020

Fecha de aceptación y versión final: marzo 2021 
